\title{
FISCAL FEDERALISM IN SWITZERLAND: \\ Relevant Issues for Transition Economies in Central and Eastern Europe
}

\author{
Bernard Dafflon and Krisztina Tóth*
}

World Bank Policy Research Working Paper 3655, July 2005

The Policy Research Working Paper Series disseminates the findings of work in progress to encourage the exchange of ideas about development issues. An objective of the series is to get the findings out quickly, even if the presentations are less than fully polished. The papers carry the names of the authors and should be cited accordingly. The findings, interpretations, and conclusions expressed in this paper are entirely those of the authors. They do not necessarily represent the view of the World Bank, its Executive Directors, or the countries they represent. Policy Research Working Papers are available online at http://econ.worldbank.org.

* The authors are World Bank consultants. This paper is part of a series of papers for the project on Lessons from Fiscal Federalism Practices directed by Anwar Shah, Program Leader, Public Sector Governance Team, World Bank Institute (ashah@worldbank.org). 


\section{ABSTRACT}

Its highly fragmented structure of local governments and serious horizontal fiscal imbalances make Switzerland a surprisingly powerful model for Eastern European countries that are currently facing the challenge of fiscal decentralization. In spite of the substantial differences in the tradition and current practice of intergovernmental fiscal relations, transition economies may learn valuable lessons from the Swiss case in the fields of direct democracy, horizontal cooperation, expenditure and revenue assignment, and fiscal discipline. Among other conclusions, the paper suggests that subnational authorities can effectively fend off recentralization attempts of the central government if they engage in spontaneous cooperation to enhance the efficiency of public service provision. Together with an adequate fiscal equalization scheme, interjurisdictional cooperation also permits the reconciliation of the objective of an increasing devolution of powers with the existing regional disparities. It is also shown that the principle of subsidiarity can best be safeguarded by anchoring the expenditure and revenue powers of subnational governments in the constitution or in a similarly strong law. With regard to fiscal discipline, the combination of a "golden rule" with direct democratic instruments of budget control is proven to be successful in enhancing the accountability of local politicians toward their constituency. 


\section{CONTENTS}

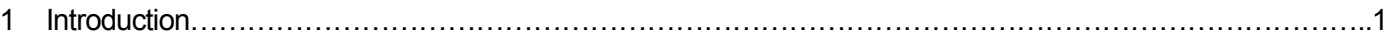

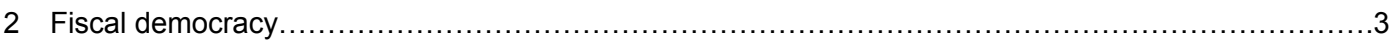

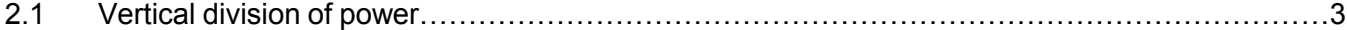

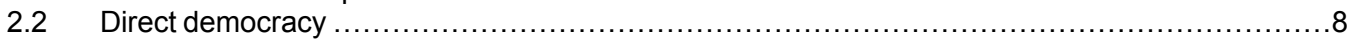

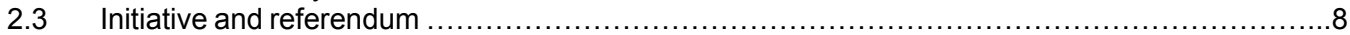

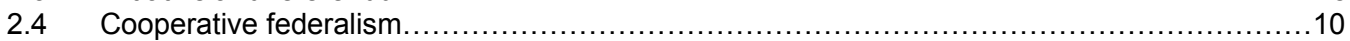

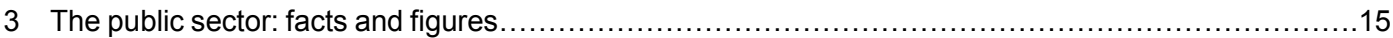

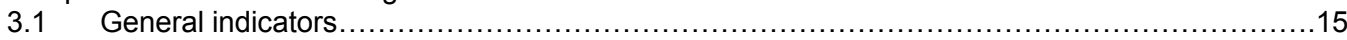

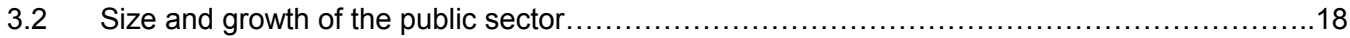

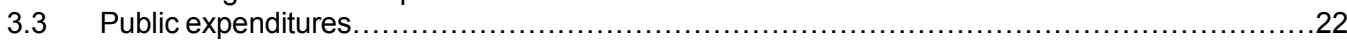

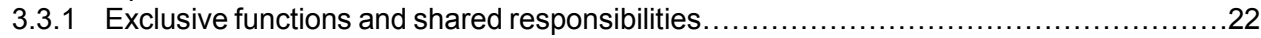

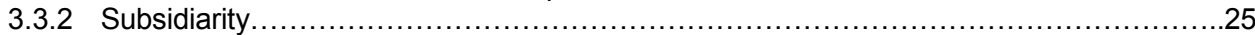

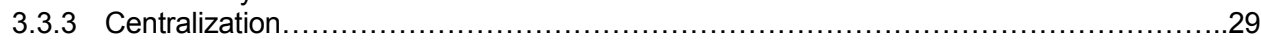

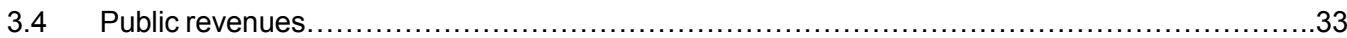

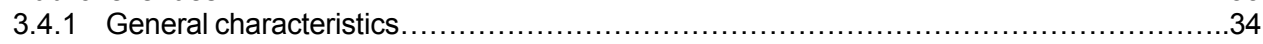

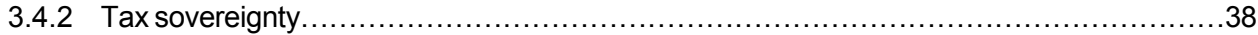

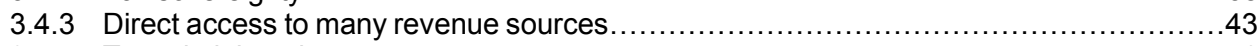

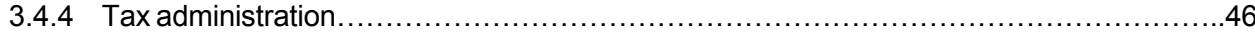

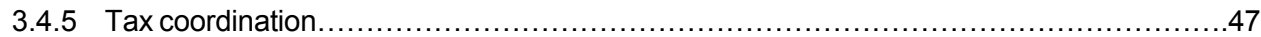

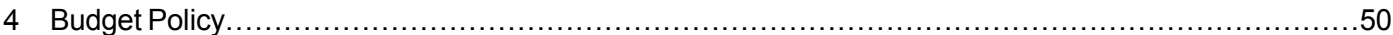

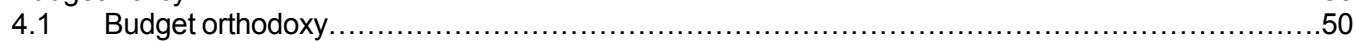

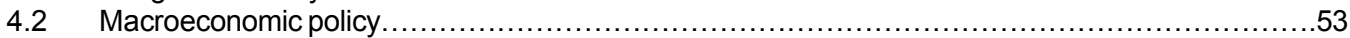

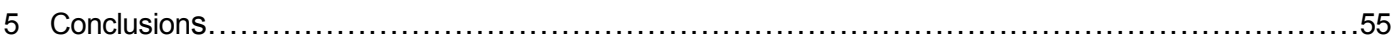

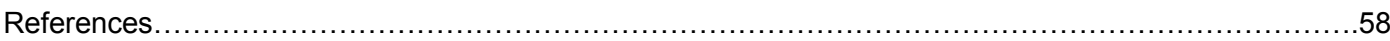

Tables

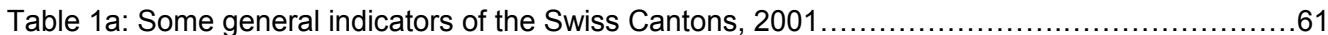

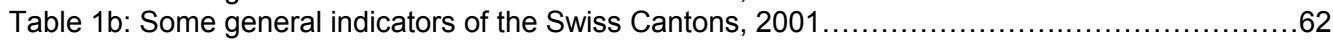

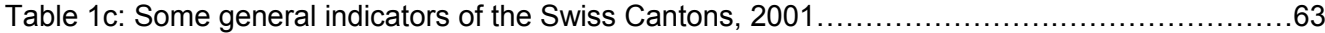

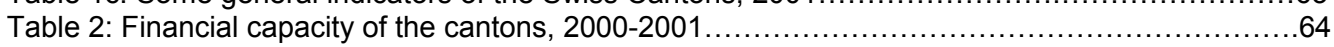

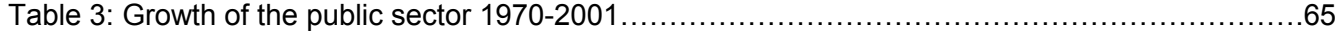

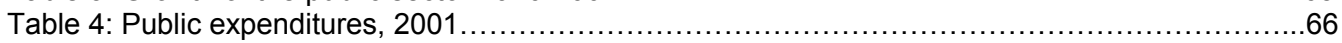

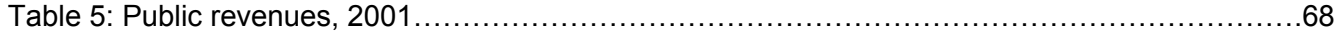

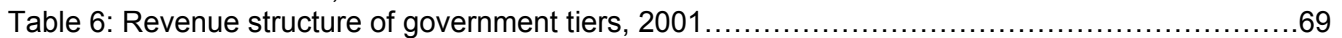

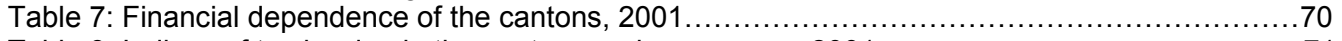

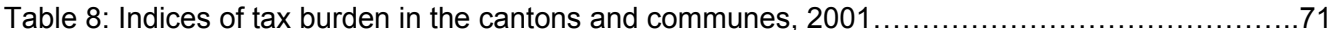

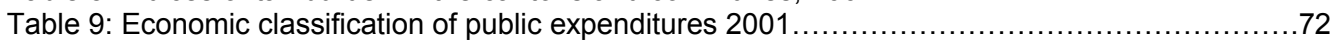

\section{Boxes}

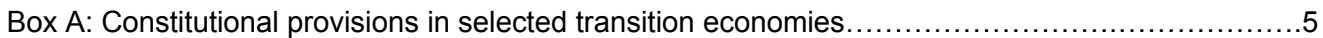

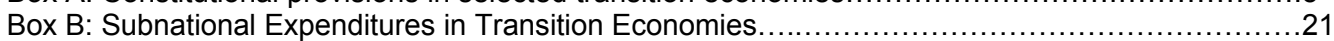

Box C: Subnational Public Revenues in Transition Economies.....................................

Figures

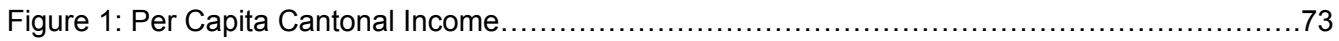




\section{$1 \quad$ INTRODUCTION $^{1}$}

This paper deals with the institutions and actual problems of fiscal federalism in the case of Switzerland. Beyond the description and the analysis of the Swiss model, the objective of the paper is to examine how it can serve to address the structural problems of fiscal federalism in the transition economies of Central and Eastern Europe (hereafter TEs). We are well aware of the difficulties that this particular theme setting may raise, and especially aware of the problem of "transplanting" elements and techniques of fiscal federalism from a genuine federal country with long historical traditions in bottom-up democracy, into unitary states with a very short history of top-down decentralization. As the OECD puts it in one of its recent studies, "economic efficiency and equity principles are often secondary to historical and political considerations. It is thus not easy to replicate the incentive structures of one country in another" (OECD, 2003: 144).

The scope of our analysis covers the decentralized unitary countries of the Central and Eastern European region: eight new member states of the European Union (Estonia, Latvia, Lithuania, Poland, Czech Republic, Slovakia, Hungary and Slovenia), two of the current EU candidate countries (Bulgaria and Romania), as well as the unitary countries of the Balkan area (Albania, Croatia and Macedonia). The New Independent States of the ex-Soviet Union are not included in the analysis. $^{2}$

The paper is divided in three sections. Starting in section 2 with a short summary of some issues in fiscal democracy that are relevant to Swiss decentralized public finance, the paper describes in section 3 the main components of the fiscal structure and the assignment of functions and revenue sources at decentralized levels, with special regard to taxation. In section 4 , two fundamental issues of budget policy are analyzed.

Since the first Constitution of 12th September 1848, Switzerland has been, in institutional terms, a relatively complex system of three layers of government: (1) the communes, at the local level, (2)

1 Unless stated in the text, all statistical data refers to 2001. Relevant issues for TEs are marked with the sign $>$ at the beginning of the paragraph.

2 We have deliberately chosen to omit the federal states of Eastern Europe (the State Union of Serbia and Montenegro, the federal state of Bosnia and Herzegovina and the Russian Federation). This strategy allows us to focus our comparison on a relatively homogeneous group, namely the unitary decentralized countries. The lessons that federal TEs might draw from the case of another federal country are likely to be very different from what unitary TEs would learn from the same 
the Cantons, at the intermediate level, and (3) the Confederation, at the national level - which are interconnected by many vertical and horizontal relationships. In 2001 there were 26 Cantons and 2880 communes (see Table 1 for some general indicators of the Swiss Cantons).

Fiscal federalism in Switzerland can be characterized in terms of overall fiscal restraint and minimizing the centralization of fiscal power. It is a "bottom-up" federalism. Constitutional arrangements, both at the federal and the cantonal levels, certainly explain this situation. The subsidiarity principle (see section 3.3.2) has been probably more scrupulously respected in this country than in many other federations because of both constitutional guarantees and a traditional mistrust of nation-wide policies. In addition, the Cantons and the communes are seen as public policy and management laboratories carrying out policy innovations without great risk for damaging the overall economy, since the upper-level government (the Confederation or the Canton) will not provide a bailout. As a consequence, the power to decide and finance the provision of public services has remained largely (and jealously) in decentralized hands, in the Cantons or in the communes. Many forms of cooperative federalism have flourished in the last decades, whether in formal institutions like the inter-cantonal treaties or informal, like the inter-cantonal conferences of ministers or those of high civil servants for various functions.

The fairly extensive autonomy of cantonal and local governments for their finance is not unlimited. First, many cantons have introduced their own constitutional rules with regard to (balanced) budget and debt limitation (section 4). Fiscal competition between jurisdictions - tough partly softened by rules of tax coordination and harmonization - is a second limit (section 3.4). However, autonomy in public expenditures, direct access to many revenue sources and, above all, differences in the Cantons' economic potential (see Table 1, columns 6 to 8 ) have led to relatively important regional disparities, expressed in the fiscal burden of the Cantons and in their financial capacity. These disparities are at the core of the Swiss equalization policy, even though there is no claim for perfect equality between the Cantons or the communes. ${ }^{3}$

country case.

3 The Swiss equalization policy is not discussed in this paper. See DAFFLON B. and S. PERRITAZ (2000b) and 
In fiscal federalism, institutions play a double role in shaping the relations between the layers of government. First, institutional arrangements should permit the jurisdictions at the decentralized (regional and local) levels, and to the civil society, to express their views on the public policies which are under discussion and take part in the process of decision-making. Second, once the decisions are taken, individual jurisdictions and citizens should accept them, even contrary to their opinion, and respect their consequences. It is therefore of interest to shed some light on the working of the institutions in Switzerland, particularly on the rules and principles, which govern the assignment of functions and revenue sources to decentralized jurisdictions. Four institutional characteristics are essential in the working of Swiss federalism: (1) the vertical division of power in the Constitutions, (2) direct democracy, (3) initiatives and referenda and (4) horizontal cooperation between governments at the cantonal and communal levels.

\subsection{The vertical division of power}

The Swiss federal system emphasizes the sovereignty of subcentral jurisdictions, i.e. the Cantons and the local communities. This sovereignty is derived from the federal and cantonal constitutions, which lists not only the tasks of each government level, but also fix their right to levy some sorts of taxes. Thus, the assignment of competencies and revenue sources is guaranteed at each level of government. The vertical division of power, intended to prevent stable majorities from being able to exploit minorities, is strongly safeguarded in the Constitution (KNAPP, 1986; ZIMMERMANN, 1987).

Article 3 of the new Federal Constitution of April 18, 1999 (Cst.) guarantees the Cantons' sovereignty in all the spheres in which the Constitution does not explicitly provide for the federal government's competence. Article 42 Cst. defines in a restrictive manner the assignment of functions to the Confederation: "it shall accomplish the tasks which are attributed to it by the

DAFFLON (2004). 
Constitution." ${ }^{4}$ Therefore, each new competence of the center requires a constitutional amendment, which necessitates the consent of both a majority of the voters and a majority of the Cantons. In contrast, article 43 Cst. stipulates that "the Cantons shall define the tasks which they shall accomplish within the framework of their powers." At cantonal level, there is no need for a constitutional explicit clarification. At the federal level, the autonomy of the Cantons is also guaranteed by the legislative power with two Chambers which have equal power (art. 148 Cst.). The National Council (House of Representatives) is elected on the basis of population in the Cantons according to the system of proportional representation. The Council of States (the Senate) consists of 46 delegates of the Cantons, two for each canton and one for each half-canton (Appenzell Rh. Int. and Appenzell Rh. Ext., Basel-City and Basel-Land, Nidwald and Obwald) irrespective of its population, size or economic and financial power. ${ }^{5}$ The Cantons regulate the election of their Senators.

$>$ Except for three states - the Russian Federation, the State Union of Serbia and Montenegro and the federal state of Bosnia and Herzegovina - none of the Central and Eastern European transition countries has a federal structure. This is mainly due to the fact that formally federal states - the Soviet Union before the end of 1991, Czechoslovakia prior to 1993, and Yugoslavia until the early 1990 s - provided rather negative examples of federalism. Initially conceived as a "brotherly association of liberated people and a convenient framework for diverting nationalism in a harmless direction" (MASTNY, 1998: 11) socialist federations turned into completely centralized states without any substantial devolution of power to constituent states, municipalities, and ethnic groups. ${ }^{6}$

All TEs reviewed in this paper are unitary countries that engaged themselves in a process of political, administrative and fiscal decentralization from the early 1990s. The constitutions of these states recognize the right of local communities to self-government, except for Latvia and Lithuania where the constitution does not contain such a provision (see line 2 in the Box A below). With regard

4 The Constitution of 1999 replaced that of 1872 which was amended so many times and overloaded with so many details that it had become difficult to read. The 1999 Cst. is not "new" in essence but reorganizes in a modern way the previously existing articles. There are only a few innovations - see note 8 . Title 3, chapter 2 of the new Federal Constitution of 1999 provides the enumeration of federal competencies. The constitutional articles also fix the role of the Cantons for those functions. It follows that for a large number of public expenditures, the Cantons have only residual autonomy and act rather as "agencies" for the center.

5 This means in fact equal power for each Senator, although a Senator of Appenzell Rh. Int. represents about 15,000 residents and a senator from Canton Zurich about 600,000 residents, that is forty times more (see Table 1, column 4).

6 For an excellent overview of the historical experience of federalism in Central and Eastern Europe, see (MASTNY, 1998). 
to the vertical division of power, however, none of these constitutions provide a similarly strong safeguard for devolution as does the Swiss federal constitution. Contrary to the power-sharing model typical to federal countries - where federal competences are enumerated and residual powers rest with the constituent states -, the constitutions of the decentralized unitary TEs define first of all the powers of the intermediate and local levels of government, and leave the residual competences to the center.

\begin{tabular}{|c|c|c|c|c|c|c|c|c|c|c|c|c|c|c|}
\hline \multicolumn{15}{|c|}{ Box A Constitutional provisions in selected transition economies } \\
\hline & & $\mathrm{AL}$ & BG & MC & CR & SL & RO & $\mathrm{HU}$ & $\mathrm{CZ}$ & SK & PL & ES & LA & LI \\
\hline 1 & Federal structure & 0 & 0 & 0 & 0 & 0 & 0 & 0 & 0 & 0 & 0 & 0 & 0 & 0 \\
\hline 2 & Local self-government & + & + & + & + & + & + & + & + & + & + & + & 0 & 0 \\
\hline 3 & Fiscal autonomy & + & 0 & + & 0 & + & + & + & + & + & + & + & 0 & 0 \\
\hline 4 & Extent of fiscal autonomy & 0 & 0 & 0 & 0 & 0 & 0 & 0 & 0 & 0 & 0 & 0 & 0 & 0 \\
\hline 5 & Competence-competence & + & + & + & + & + & + & + & + & + & + & + & + & + \\
\hline 6 & Number of subnat. gov. tiers & 2 & 2 & 1 & 2 & 3 & 2 & 2 & 2 & 3 & 3 & 2 & 2 & 3 \\
\hline 7 & - of which: democr. elected & 1 & 1 & 1 & 2 & 2 & 2 & 2 & 2 & 2 & 3 & 1 & 1 & 1 \\
\hline \multicolumn{15}{|c|}{$\begin{array}{l}\text { Legend: } \\
\mathrm{AL}=\text { Albania, } \mathrm{BG}=\text { Bulgaria, } \mathrm{MC}=\text { Macedonia, } \mathrm{CR}=\text { Croatia, } \mathrm{SL}=\text { Slovenia, } \mathrm{RO}=\text { Romania, } \mathrm{HU}=\mathrm{Hungary}, \mathrm{CZ} \\
=\text { Czech Republic, } \mathrm{SK}=\text { Slovakia, } \mathrm{PL}=\text { Poland, } \mathrm{ES}=\text { Estonia, } \mathrm{LA}=\text { Latvia, } \mathrm{LI}=\text { Lithuania. } \\
(+) \text { the issue appears in the constitution, }(0) \text { the issue does not appear in the constitution. }\end{array}$} \\
\hline \multicolumn{15}{|c|}{$\begin{array}{l}\text { Source: (ADAMOVICH 2003: 130). The data for SK and SL have been updated following the establishment of } \\
\text { regional self-governments in 2001/2002. The records for ES, LA and LI have been added by the authors. Line } 6 \text { : } \\
\text { the NUTS-II level administrative regions that were established with the sole aim of managing EU Structural } \\
\text { Funds are not considered. }\end{array}$} \\
\hline
\end{tabular}

$>\quad$ While local autonomy is generally recognized by the constitutions of unitary states, and subnational jurisdictions are most often granted some budgetary autonomy (line 3), the extent of this autonomy is not defined (line 4). Rather there are constitutional provisions that give the parliament the highest competence to decide about the budget of the entire government sector including subnational governments ("competence-competence", line 5). This manifests itself most commonly as the power of the legislative branch to determine the national budget, taxes and public fees. Constitutions that stipulate the right to local self-government usually also contain a promise that 
mandated responsibilities of local units shall be financed from the central budget. The limits of subnational fiscal autonomy, however, are defined in separate laws. This may provoke serious problems when it comes to the demarcation of expenditure authorities between government tiers (see section 3.3.2).

The vertical division of power in Switzerland leaves a high degree of autonomy to the Cantons but also creates problems for the larger municipalities. On one side, the Cantons have their own fiscal systems that are, for a substantial part, independent from the federal system. The Cantons are therefore able to set their own tax rates, and they decide on the provision of public goods and services on their own. Although the modification procedures are long and complex, each voter/taxpayer in a canton or in a commune is able in the end to compare the costs and benefits of the public activity under consideration and to decide on the amount of public expenditure in a vote or in a referendum. However, on the other side, large municipalities or agglomerations, like that of Zurich, which alone has more residents than the five neighboring Cantons, create spillovers over cantonal boundaries, but do not have the legal possibility of negotiating directly with municipalities beyond those cantonal borders.

Up to the new 1999 federal Constitution, fiscal arrangements have been discussed either at the federal-cantonal levels or at the cantonal-local levels. The federal government addressed itself always and exclusively to the Cantons. It could not by-pass cantonal governments to address local governments either to impose or to negotiate fiscal or financial matters or the provision of public services. The inverse was also true: local governments could not by-pass cantonal authorities; they had no direct access to federal bureaus or institutions. In this way, federal decisions concerned the Canton only; and each canton organized communal competencies on its own. Although agglomerations have a statistical definition, and have been an expanding economic reality for the last decade, only the new 1999 Federal Constitution gives them an institutional recognition. ${ }^{7}$ Rapidly, local authorities in large urban areas have claimed a right to address the federal state directly, particularly where the agglomeration boundaries encompass several cantons. But a direct

7 The Federal Constitution of 1999 contains for the first time an explicit reference to the communes and municipalities. Art. 50 says: "(1) The autonomy of the communes is guaranteed within the limits fixed by cantonal law. (2) In its activity, the Confederation shall take into account the possible consequences for the communes. (3) In particular, it shall take into account the special situation of cities, agglomerations, and mountainous regions." 
relation between an individual commune and the center is not in the tradition of this country and will probably still not be so for many years to come. This has led to the setting up of a tripartite committee, in February 2001, with representatives of the association of Swiss cities and agglomerations, the Cantons and the Confederation (DAFFLON and RUEGG, 2001: 43-45). What will be the effective consequences of article 50 of the Federal Constitution and the policy proposal of this committee is not yet clear.

$>$ In all TEs within the scope of our analysis, the central government and the municipal governments are allowed to address each other directly, by-passing the intermediate level(s) of government. In Hungary and Albania, by-passing the intermediate level in the communication between municipalities and the central state is not an exception, but the rule. Both local and provincial (county or district) governments are directly accountable to the central government, so that the intermediate level does not have control power over municipalities in any circumstances. Without questioning the reasonability of these practices in their specific contexts, it must be noted that the reasons here are much different from those in the Swiss case. Instead of the growing needs of urban agglomerations, by-passing the intermediate level in Eastern Europe signals the need for a strong control of central government over local spending behavior, in the interest of macroeconomic stability.

In Switzerland, the lack of direct contact between local and national authorities may in fact lead to awkward situations, especially when Cantons hinder their constituent local governments from expressing their complaints about cantonal authorities toward the federal government. On the other hand, one can question why municipalities in large urban areas, with spillover effects spreading out on municipalities in neighboring cantons (as is the case in Zurich), should address themselves directly to the federal government for solving urban problems. Normally, federal government should deal with nationwide issues rather than with the problems of particular urban areas which, however important they may be, rest on a subnational scale. In Switzerland the argument goes that if the same types of problems arise in most urban areas, the federal government should bother and intervene to provide a general legal framework that allows local solutions and prevents local authorities from pursuing free-rider strategies. 


\section{$2.2 \quad$ Direct democracy}

Direct democratic participation is provided in most cantonal constitutions for the communes so that citizens themselves may take part in the decision-making process on all important political and economic issues. In local public finance, this competence concerns the current budget, the annual tax coefficients, user charge regulations (taxation according to the benefit-principle in general), individual investment items of the capital budget, local public property sale or purchase, horizontal cooperation in the form of inter-communal association or special purpose district for the joint production of public facilities, and the amalgamation of communes.

In addition to participation, control and audit competencies of some sort exist in all direct democracies. The communal assembly of citizens, or the communal "parliament" where it exists, elects a finance committee for the length of the political term of office. This committee has not only traditional audit competencies, but also the duty to report to the assembly about changes in taxation and user charges, and about the financial aspects of capital expenditures. In addition, it has the powers to investigate financial matters without warning if necessary. In some cantons, it may lodge a complaint against individual members of the local authorities for misuse of public funds.

\subsection{Initiative and referendum}

When democracy is representative, which is the case in a large majority of the Cantons and in large cities, voters express their preference about political and economic issues mainly via referenda, which may be brought up for vote several times during a year. Together with popular initiatives, these institutions play a role of moderator for cantonal and local governments, as usually all important public decisions are subject to the voters' approval. ${ }^{8}$ At the local level, the most common items which might be included in the initiative or the referendum procedure are: taxation, user charge regulations, individual investment items of the capital budget, property sales, cooperation in inter-communal associations or special purpose districts, and the merging of communes.

8 In most Cantons, constitutional or legislative initiatives are possible on taxation and user charges, new repetitive current expenditures or single capital expenditures, which require a minimum number of citizens' signatures. Referenda against capital, unique or recurrent expenditures are also possible. The institutional and legal conditions about the distinctions between compulsory or facultative referendum, unique and recurrent expenditure, capital or current expenditure, the number of signatures required, the time allowed for collecting the signatures, differ widely from one canton to another. While the influence of referenda in general on the outcome of the public budget are known, the influence of the detailed cantonal 
Obviously these institutions of the federal system do not have a unique purpose of (economic) efficiency in the performance of expenditures and taxation. The more direct and democratic the institutions are, the better is their general capacity to strengthen the system of checks and balances, by both dividing and sharing political decision-making power. They give citizens/voters/taxpayers multiple access to government, increase their capacity to control the budgets and reduce political and bureaucratic leeway in rent-seeking behavior. In HIRSCHMAN's terminology, they not only have the "exit" (Tiebout-style mobility), but also the "voice" solution. As a result, the growth of the government sector is significantly lower than in representative democracy (POMMEREHNE and SCHNEIDER, 1978), the size of government is limited (POMMEREHNE, 1978) and public expenditures are driven by the demand side (KIRCHGÄSSNER and POMMEREHNE, 1990), (KIRCHGÄSSNER, FELD and SAVIOZ, 1999).

D Direct democracy in TEs enjoys an ever growing importance but has by far not exhausted its potential. Today in the vast majority of TEs referenda, initiatives and public hearings are provided for in the national constitution or in the act on local government. In contrast with the Swiss case, initiatives in TEs may not directly lead to the introduction of a new regulation but simply launch a debate or a referendum on key municipal issues. Municipal councils may be obliged to call a referendum on certain issues and hold facultative voting on other issues, but in many cases the results are advisory in nature. Referendum, along with other forms of direct democracy, has not been used very intensively in TEs, and both the design of such referenda and the rate of participation have been rather poor. In addition, there is scope for further improvement in the enforcement of existing laws concerning citizens' rights to direct democratic participation.

$>$ The main reason for the low level of utilization of direct democratic instruments could be the fact that open communication and the exchange of different political ideas are not yet anchored in the habits of citizens and politicians. On the other hand, as Frey points out, the oppressive and authoritarian governments during the socialist era encountered little opposition, as citizens feared that expressing their true views could entail sanctions. Hence politicians could think, wrongly, that

referendum conditions, as a measure of budget orthodoxy, on public deficit and the indebtedness of the Cantons are presented in (PUJOL, 2000) and (NOVARESI, 2001). 
the population was not interested in their decisions (FREY, 2003: 44). The majority of Central and Eastern European societies demonstrate a marked improvement in the participation rates. However, development was suddenly broken in ex-Yugoslavia where the devastating effects of the war made citizens wearied and indifferent to local politics, despite the well-developed culture of public participation and local self-management during the socialist era. Ignorance and indifference towards direct democracy in Eastern Europe is not easy to fight down today, as the agenda of local referenda continues to be restricted to a few formal issues, such as the amalgamation and separation of municipalities, intercommunal cooperation arrangements and public investments. In Hungary, Bulgaria and the Czech Republic, issues related to the municipal budget and the introduction of local taxes and fees must not be addressed by referendum. Citizens' interest for direct decision-making obviously falls if referenda are only held on issues of marginal importance. Given the risks involved with economic and political transition, leaving all revenue and expenditure decisions to be decided in the framework of representative democracy is a rational means of controlling the macroeconomic situation of the country. As decentralization proceeds, however, the scope for direct participation may well grow larger in the near future, at least at the municipal level.

$>$ A better implementation of the existing rules of direct democracy and the extension of the range of issues tackled in referenda and other institutions are likely to enhance citizens' interest in local politics (BENZ and STUTZER, 2002). Simultaneously, they increase the accountability of subnational governments towards their electorate. Referenda can also help to detect the preferences of large minorities and thus channeling intercultural or interethnic conflicts into a more democratic political process. In general, direct democracy enhances social capital (trust and honesty), which in turn affects the development of the economy in terms of both per capita income and subjective wellbeing (FREY, 2003).

\subsection{Cooperative federalism}

In Switzerland, the federal and cantonal Constitutions permit intensive horizontal cooperation at the cantonal and communal levels of government. Horizontal cooperation is important for Olson's principle of fiscal equivalence (OLSON, 1969; VON HAGEN, 2003: 374 f.), so that the circles of deciders, beneficiaries and payers coincide. Cantons and municipalities are free to conclude agreements with one another on cooperation in the most varied areas and so establish themselves 
the optimum size of area necessary for the performance of government tasks, for example the provision of certain public goods, from university funding (inter-cantonal cooperation) to school districts and water provision (inter-communal cooperation). ${ }^{9}$ At the local level, where self-governing units are too small for providing local public services on their own, inter-communal cooperation is a viable solution. It helps not only to realize economies of scale, but also to avoid creeping cantonalization of local competences under the pretext that municipalities are too small and hence not efficient enough. At the cantonal level, the image is more contrasted: whereas inter-cantonal agreements are quite a success for several cantonal public policies and functions (university funding is an example), they have failed with regard to preventing harmful tax competition, the law on tax harmonization being left widely ignored or without real content against the arguments of regional autonomy in growth policies.

$>$ While the size of municipalities in Lithuania, Bulgaria and Poland (in terms of population) is comparable to the average local government size in Scandinavian countries, the rest of TEs are marked by a severely fragmented territorial structure. The municipalities in Hungary, Slovakia and the Czech Republic are the smallest throughout the Eastern European countries reviewed, with an average population of 1,700 to 3,300 . In all three countries, more than $90 \%$ (CZ and SK: more than $95 \%$ ) of all communes have less than 5,000 inhabitants (FEKETE et al.; 2002, KLING et al., 2002; LACINA and VAJDOVA, 2000). The reason of this fragmentation is a historical one. The structural reforms introduced during the socialist period usually led to the enlargement of local government units. From the 1990s, as a reaction to this forced amalgamation, thousands of municipalities decided to split up, so that the number of local units currently exceeds the original level of the early 1950s. Similar to the Swiss case, small local government units cope with substantial deficits in their accounts or deficiencies in the provision of local public services - as they fail to realize the economies of scale. In order to enhance the efficiency of public service provision, central governments in all TEs allow and even promote horizontal cooperation, but the number of municipal cooperation agreements is still below the desirable level. This is partly due to the fact that municipalities, glad to have been relieved from centralized bureaucratic control, are reluctant to give up their autonomy. Another reason may be that the majority of small municipalities are still not

9 New forms of inter-cantonal cooperation, called FOCJ for "Functional, Overlapping and Competing Jurisdictions", are 
familiarized with the modern management methods which would allow them to enhance the efficiency of public service provision. For sure, as long as grants from the central government ensure a comfortable and more or less reliable source of local income, municipalities will not be particularly motivated to beat down costs through intercommunal cooperation. With an increase in tax autonomy on the medium and long term, however, local governments are likely to become more interested in low-cost operations. In the short run, financial and legal incentives might present a bridging solution. Especially in the new member states and the candidate countries of the European Union, inter-communal arrangements are highly encouraged through favorable legislation and unconditional grants-in-aid. The aim of this policy is to create optimum-sized jurisdictions that are able to accommodate development projects in the framework of the EU Structural Funds. As the case of Switzerland shows, voluntary cooperation can and must be encouraged, as it helps to avoid the recentralization of local tasks.

Horizontal "face-to-face" cooperation between the Swiss Cantons has taken another form which was not foreseen in the Constitution. When the need for a nation-wide steering policy arises, fiscal federalism in theory suggests that this should be realized at the center, by the federal government. This is not always the case in Switzerland where the Cantons have organized themselves horizontally in a set of powerful committees, the so-called Conferences of Cantonal Ministers, one for each department in the administrative division of government executives, of which the Conference of the Cantonal Ministers of Finance (CCMF) is the most influential. From a constitutional point of view, fiscal/financial relations between the federal government and the Cantons cannot be tailored according to individual cantonal particularities or wishes. Equality of treatment applies, except within the equalization law. Although each canton could challenge or negotiate individually fiscal/financial arrangements with the federal government, no single canton would have much chance in succeeding in modifying fiscal/financial arrangements for its own objectives, since any change applies (and indeed should be acceptable) to the other cantons. Within the Conferences, the Cantons negotiate common policies without interference from the center, then present a common package to the federal government. The objective of the CCMF is to discuss fiscal/financial matters which are of common interest to all or a large number of the Cantons. It has been organized not so much to coordinate and harmonize fiscal and financial affairs of the Cantons 
(horizontal relations), as to intervene more persuasively in federal-cantonal relations and to interfere in federal-only fiscal and financial matters. The Conference is not a constitutional institution. Yet, fiscal matters cannot be decided at the federal level without previous consultation of the CCMF. It is a powerful pressure group, regularly consulted by the federal Finance Administration. It has been successful in negotiating global financial packages in which the point of view of the Cantons differs from that of the federal government. It has played an important role in shaping federal finance, the federal tax system and tax harmonization, which was to remain "formal", and has a dominant position in federal equalization policies (DAFFLON, 1995).

The Conference of the Cantons $(\mathrm{CdC})$ also exerts a powerful balance against federal policy proposal. The whole process of a New Fiscal Equalization package, for example, which is presently under discussion, is a joint venture of the Federal Ministry of Finance and the CdC. Both the Conference of Cantonal Ministers and the Conference of the Cantons might be a food for thought for TEs, although on the medium term it is not very likely that their intermediate-level self-governments (where they exist) would gain a similarly influential position within the public policy arena. However, such representation of intermediate level interests may also be effected through cooperation among line ministry officials. In a substantial number of transition countries the intermediate level still consists of purely administrative territorial units of the central government, and in several others the provincial self-governments are under the strict control of parallel government agencies or line ministries. This by itself does not exclude the possibility that policy experts in the administrative territorial units, showing a great deal of expertise on the issue under discussion, carry out successful lobby-work vis-à-vis the related ministry of the central government. In the same vein, the Swiss experience shows that at local level such Conference of local government specialists on specific issues (for example social aid, local finance, territorial planning or primary education) are often more efficient in negotiating policy solutions with the Canton than the official association of municipalities.

At the local level in Switzerland, the main incentives for inter-communal cooperation are, traditionally, economies of scale and regional spillovers and, more recently, limited managerial skills in many small municipalities, especially when local governments function as production agencies for the center (Cantons or Confederation), as for example in the field of national environmental policies. Contrary to other federal countries and to most of the TEs, there are no deconcentrated "federal 
agencies" that, acting as regional or local producers of services for the provision of public services, have to respect minimum standards set by the central government. The Cantons perform as "agents" of the center (the "principal") but may decide on their own how they wish to implement those services. Usually, these services are in turn assigned to the local tier. There is no duplication of similar producing organizations at the decentralized levels.

At the local level, there is no doubt that the opportunity to create inter-communal institutions has been largely used by the municipalities and has improved efficiency in producing and delivering local public services. According to a recent survey by LADNER et al. (2000: 71 ), there are around 20,000 ad hoc institutions or specific units of inter-communal cooperation for less than 3,000 municipalities. But the multiplicity of inter-communal special purpose districts has created several institutional problems as well: a democratic deficit in the regime of communal assembly or local parliament, higher information and participation costs for individual citizens who henceforward belong not only to one commune but to several other "clubs", strategic blockages of votes by negotiating communes when a qualified majority is required, and the like (DELLA SANTA, 1996). This is actually a general problem in TEs, too. Besides, the general lack of cooperation skills, the fear of democratic deficit are major obstacles on the road to broadening cooperation, although the law provides for the possibility to create inter-communal institutions.

Despite these inconveniences, it may be precisely this executive flexibility of federalism which has long made it resistant to attempts of centralization on the part of the federal government vis-àvis the Cantons, or on the part of the Cantons vis-à-vis the communes. It also explains why so many small communes can survive without merging and why the compulsory merging of too small communes is not easily accepted by the citizenry. 
This section summarizes the overall present situation of the public sector in Switzerland at the three tiers of government. All figures are based on 2001. Tables 1 to 8 also exist for the period 1990 to $2000:{ }^{10}$ but there have been no significant changes over this last decade. Section 3 is divided in four sub-sections: (a) general indicators concerning the Cantons, (b) the size and growth of the public sector, (c) public expenditures and (d) public revenues. Whenever possible, the current state of research on fiscal federalism in Switzerland is mentioned.

\subsection{General indicators}

The institutional issues presented in section 2 have of course a price to be paid in terms of economic efficiency and equity. The solutions and practical arrangements do not exactly correspond to the canon of fiscal federalism in the textbook. And they do not permit to level out all differences in the economy and the public sector. A few statistical data will illustrate this argument. Table 1 (Tables are given at the end of this paper) gives five general indicators about the organization and the economy of each Canton: the number of communes, the surface in $\mathrm{km}^{2}$, population (total and density), national income in the Cantons (NIC) total and per capita, and a number of figures for public expenditures and revenues at the cantonal and communal levels.

Marked differences exist in the organization of local government, the number of communes, in size, population and national income, that one probably does not find in another federation.

$\checkmark$ The number of communes in individual canton varies from 3 in Basle-Town to 400 in canton Bern; the number of municipalities has no correlation with the population size: with almost the same total population, Thurgovie, Soleure and Fribourg have respectively 80, 126 and 226 municipalities.

$\checkmark$ The area of the smallest Canton (Basel-Town, $37 \mathrm{~km}^{2}$ ) is $0.5 \%$ of the area of the largest (Grisons, 7,105 km²).

10 Readers interested in the statistics of the preceding decade are requested to contact the authors. 
$\checkmark$ The population in the least populous Canton (Appenzell Rh. Int.; 15,000 residents) is $1.2 \%$ of that in the most populous (Zurich; 1,229,000 residents).

$\checkmark$ In 2001, the Canton with the highest NIC was Zurich, with a total of 72,504 million SFr., that is $21 \%$ of the NIC for $17 \%$ of the population. The variation in per capita NIC is rather large: from $71,733 \mathrm{SFr}$. in Zug to $33,616 \mathrm{SFr}$. in Jura, that is a ratio of 2.1 between the two Cantons with the highest and the lowest per capita NIC (or a range from 153 points to 72 points, for an average 100 points $=46,970$ SFr. per capita).

There are also:

$\checkmark$ Marked differences in the growth of per capita NIC between 1980 and 2001 (in real values). In 14 of the 26 Cantons, the rate of growth has been higher than the national average of $18 \%$ for the period (that is on average less than $1 \%$ annual for the 21 -year period), with a maximum at $38 \%$ in Schwyz and a minimum at $1 \%$ in Geneva (Table 1, column 8 ).

Figure 1 also presents the comparative position of the Cantons in comparing their NIC per capita for 2001 in nominal values (national average: 46,970 Sfr.) on the horizontal line and the growth of per capita NIC between 1980 and 2001 in real value (Table 1, columns 7 and 8) in vertical. The graph shows that, after some thirty years of national fiscal equalization policy and as many years of regional development policies, the cantons are mainly distributed into three quadrants, but for three of them:

- at one end, in the top right quadrant, 8 out of 11 Cantons with higher-than-average 2001 NIC per capita are also ahead in terms of growth;

- in the bottom left box, 9 Cantons have remained in a bad position, with at the same time a NIC per capita and a rate of growth below national average;

- six Cantons (Uri, Appenzell Rh. Ext., St-Gall, Thurgovie, Lucerne and Appenzell Rh. Int.) have registered an improvement, with still lower-than-average NIC per capita but higherthan-average rates of growth; 
- the cantons of Basel-Town, Geneva and Glaris are the exceptions, with a lower-than-average rate of growth (bottom right box).

From this performance, one cannot say that both equalization and regional development policies have been very successful. Though it must also be remembered that the federal equalization policy has not a total "gap-filling" objective in setting revenue sharing formulas or equalizing grants.

$\checkmark$ The financial capacities of the Cantons, represented in the official indicators given in Table 2, is yet another mean of measuring the economic disparities between the cantons. The total index contains four components, given in columns 2 to 5 . For each component, the national average is marked with 100 points and the columns demonstrate the relative position of the cantons. The inverse of the tax burden corresponds to the formula \{a tax indicator, the inverse of the global index of tax burden in canton "i" (that is, for each canton, 100 divided by the average global index of tax burden for 1995-1998; for the standard composition of the tax burden index, see Table 8)\} and gives the relative weight of five major tax sources in the cantons. Tax revenues, in column 4, stand for a sort of a Representative Tax System: it is the sum of cantonal and communal tax yield of the same four major taxes, weighted by the previous index so that the cantonal results are comparable. The fourth component is a normative measure of the cantons' expenditure requirements (needs or costs, this is not clear), combining population density and the importance of rural versus urban areas. The total index for the individual cantons varies from 30 points in Valais to 218 point in Zoug, for an average of 100: this is a 7.27 min-max ratio used for fiscal equalization. But the weighted average before correction is 73.90 points in Valais for 143.5 point in Zoug, that is a 1.9 min-max ratio. ${ }^{11}$

Disparities of similar magnitude are observed in several transition economies. More than a third $(35 \%)$ of the gross domestic product of Slovenia is produced in the Osrednjeslovenska region, which is more than the output of the eight regions with the lowest GDP combined $(31.3 \%){ }^{12}$ While per capita GDP in the Czech Republic is almost evenly distributed across the rural regions $(11,800$

11 For a detailed analysis of the cantons' financial capacity, see DAFFLON, 2004.

12 Source: Statistical Office of the Republic of Slovenia, National Accounts First Release No. 88, June 23, 2004. 
euros on average in 2000), it is almost three times higher in the capital city (30,667 euros). ${ }^{13}$ Similarly, there are remarkable differences in the population size as well as in the geographical area across intermediate level units. The most populous administrative region (Sofia city) in Bulgaria counts almost 9 times as many inhabitants as the least populous one (Vidin), and if only rural regions are considered, the differential is 5.5 (IVANOV et al., 2002: 178). In Hungary, the difference between the smallest and largest county in terms of area is 16 -fold (but only about 4-fold if the capital is ignored). Disparities at the local level are even more striking, with the largest municipality in Hungary (Budapest) counting 1.8 million inhabitants, the second largest 206,000 and the smallest one only $12 .{ }^{14}$ Upon the basis of the Swiss example, the following sections of this paper will provide evidence that the ambitions for a successful fiscal decentralization are not necessarily frustrated by extreme interregional disparities.

\subsection{Size and growth of the public sector}

Differences in the public expenditures of the Cantons and the size of the cantonal public sector expressed in proportion of NIC are important: it runs from $11 \%$ in Zoug to 33(-)\% in Basle-Town in the first group of cantons with high financial capacity, and to a record $33(+) \%$ in the canton of Jura. Yet this comparison must be interpreted with caution. Due to the strong organizational autonomy of the cantons, the distribution of competencies between the cantonal and the local layer varies from one canton to another. Hence, for any comparison, the two layers must be considered in their totality. Taken together, the average size of the cantonal and local public sector is about $31 \%$ of NIC, with $19 \%$ for the cantonal level and $12 \%$ for the communes (Table 1, column 12 and 17). However, this proportion varies greatly across the cantons: the importance of the local public sector is less than $1 \%$ of NIC in canton Basle-Town while it is almost $21 \%$ in canton Neuchâtel. Regarding the proportion of local expenditures to cantonal public expenditures, the vertical assignment of functions results in four categories:

- in eight cantons (Basel-Town, Geneva, Nidwald, Basel-Land, Uri, Appenzell Rh. Int., Fribourg and Obwald) the cantonal public sector is almost twice as important as the communal one: the ratio "cantonal/local" is close to 2.0 ;

13 Source: Selected Indicators by Region, Czech Statistical Office, 2001. The data are calculated on purchasing power standard.

14 Source: National Association of Small Municipalities, Hungary. 
- eight cantons show a ratio of about 1.5;

- in another seven cantons, the ratio is around 1.3;

- finally, there are only a few cantons where the local public sector has almost the same size as the cantonal one (Zurich, Schwyz and Neuchâtel).

There is not a single canton where the proportion of local public expenditures to NIC is higher than the respective figure for the canton (Table 1 , columns 12 and 17).

Table 3 shows the size and growth of the public sector over the period 1970 to 2001. In 2001, total public expenditures amounted to 156,780 million SFr. This includes (vertical) financial transfers between government layers or $31 \%$ of the gross domestic product (GDP) without social security contributions (43\% with social security contributions). In proportion to GDP, the size of the public sector is still quite limited in comparison to other countries in Europe. The growth of public expenditures has been quite important both in relative and absolute values in two periods: 19701980 and again 1990-2000. The relative share of the total public sector within GDP rose 4 percentage points in both decades but remained stable around $26 \%$ between 1980 and 1990 . It regained proportion in the last decade, partly because the economic situation deteriorated and partly because social aid expenditures and unemployment benefits increased above historical levels.

The rates of growth of public expenditures for each layer of government followed a different trend over the period (Table 3, columns $6,9,12$ ). At the local level, the communes accounted for a considerable increase of public outlays in the decade 1970-1980, with a rate of growth at $141 \%$ which is higher than the total average. However, the subsequent periods witnessed a continuous decrease in the public expenditure growth rate, so that it sank to $34 \%$ between 1990 and 2000 which is much lower than the average for the entire public sector (45\%). This may be interpreted as a sign of good expenditure management - which is partly true because the communes are the first to react (and they react rather rapidly) to economic changes. But for the entire period, the figures also suggest creeping centralization towards both the Cantons and the Confederation: the rates of growth of cantonal public expenditures were above national average in the 1990s and 2000s. The actual shares of the Confederation, the Cantons and the communes in total public expenditures correspond in aggregate values to 33,41 and $27 \%$. The repartition has remained stable for the 
Confederation for almost 30 years around $31-32 \%$. At the cantonal level, the share of total expenditures has been increasing from $39 \%$ in the 1970 s to $41(-) \%$ in 2001. In difficult times (19902000) a soft trend toward centralization at the cantonal level with the communal layer losing weight is perceptible.

In all of the transition economies reviewed, the role of the public sector has significantly decreased, with general government expenditures accounting for $45-60 \%$ of GDP at the end of the last decade, which is still higher than the euro area average of 48-50 \% (OECD 2004: 239; IMF 2003a, 2003b).

$>$ As for the role of subnational governments, the number of their expenditure competences has substantially increased since the beginning of the 1990s. However, subnational expenditure levels still account for only 4 to $13 \%$ of national GDP and 8 to $23 \%$ of general government expenditures (see Box B below). One reason for these low rates is the general decrease in the volume of the public sector, which is due to a sudden drop in the GDP immediately after transition, accompanied by comprehensive macroeconomic stabilization programs. Poland, Hungary and the Baltic states show subnational expenditure rates high above the average, due to the gradual extension of the competences of local governments during the 1990 s. Compared with the $41+27 \%$ expenditure share of subnational governments in Switzerland, the figures for Central and Eastern Europe indicate that there is scope for further expenditure devolution.

D A remarkable feature of TEs is the relatively weak role of the intermediate tier in public service provision. In the constitutions of most Central and Eastern European states there is no clear commitment in favor of the provincial (county, district) self-government. (In Bulgaria, Estonia and Lithuania elected self-governments at the intermediate level do not exist: the regional or district administration is part of the central government administration.) In the framework of the top-down decentralization process starting from the early 1990 s, priority was mainly given to the restoration of self-government at the municipal level, whereas the role of the regions (or more broadly, the intermediate level of government) always remained uncertain (MARCOU, 2002: 16). The weak constitutional position of the intermediate level self-governments in TEs is partly due to the fact that, under the socialist regime, the soviet-type provincial councils acted as agencies of the center, 
receiving more and more power from the central state to ensure totalitarian control over policymaking at the municipal level. Even after the first democratic elections had taken place at the national, regional (provincial, district) and local level, municipalities preserved a suspicious and fearful perception of mid-tier governments. Nevertheless, the new wave of regionalization may help to dissipate the concerns of local politicians.

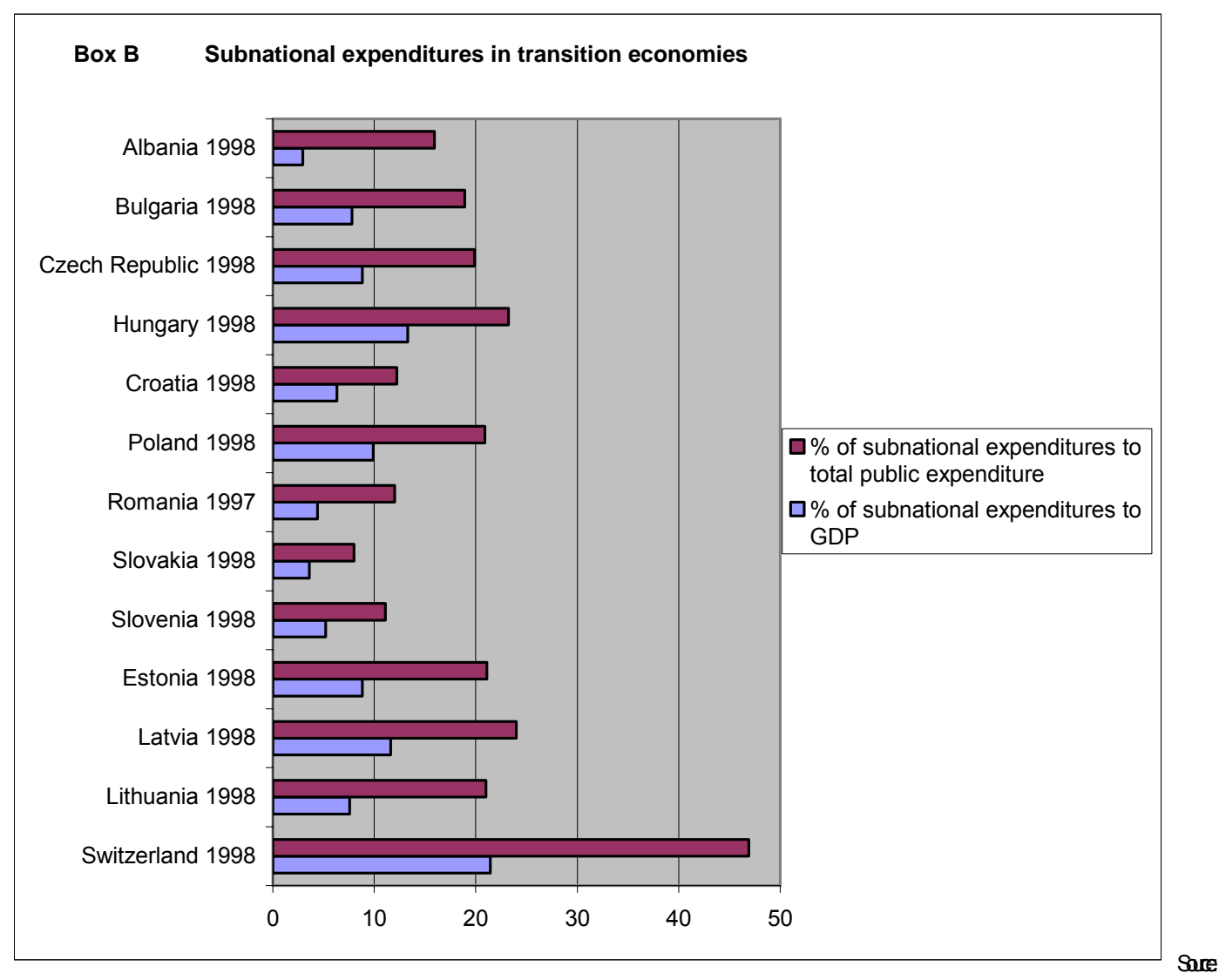

(WORLD BANK, 2004; IMF 2003a, 2003b). Macedonia: data not available.

As Marcou observes, the prospect of European integration pushed the issue of regionalization on the forefront of the political agenda during the 1990s. In the first phase of these territorial reforms, the focus is not so much on the socio-economic dimension of regions as on the formal institutional changes (MARCOU, 2002: 14). Nevertheless, most TEs which conduct a regionalization program are very clear about their intention to fill the newly created institutional structures with genuine economic and political content. This is expected to result in a considerably strong intermediate level of government. An additional challenge will be to delineate the competences of the democratically 
elected regions against those of the deconcentrated bureaus (see section 3.3.1). 


\subsection{Public expenditures}

The assignment of functions between the three tiers of government has been continuously changing over the 150 years of the Swiss Confederation's existence. The optimal division of competences depends upon the historical and actual state of intergovernmental relations, thus the question of which tasks should be assigned to which level of government has never been given a definitive answer (DAFFLON, 1992). The division of public expenditures may be explained in terms of subsidiarity and centralization. However, it must be noted that the whole process has been laborious and rather conservative, political strategies and bureaucratic locking often jeopardizing the results.

Articles 54 to 125 of the 1999 federal Constitution contain an exhaustive and detailed enumeration of the federal competencies. The Constitution always states whether a function is an exclusive federal or cantonal matter and, with shared responsibilities, the limits of central interference in the cantonal functions.

\subsubsection{Exclusive functions and shared responsibilities}

Total expenditures for each function performed by the three levels of government are summarized in Table 4. Responsibility is shared, to some degree, by the three layers of government in almost all fields of public intervention. Obviously, the Confederation is solely responsible for foreign affairs and to a less-than-full extent for national defense (91\%). But other items, like education, culture, sports and recreation, health, environment, roads, generally remain the main responsibility of the Cantons and the communes.

Table 4 also indicates the respective shares of public expenditures in proportion of the total budget of each of the three layers (column "within" - vertical) and the proportion between the three tiers (column "between" - horizontal). If we look at which governmental tier is the biggest spender in single items : 
(i) the communes have the highest share in the budget items: environment (61\%), culture, sports and recreation (51\%), administration (41\%);

(ii) the Cantons have a dominant position in public order (66 \%), health (58\%) and education (54 $\%)$;

(iii) The Confederation has an exclusive position in foreign affairs (100\%), a dominant position in defense $(91 \%)$ and assumes more than half of the public expenditure in finance $(58 \%)$.

(iv) Although the cantons and the communes together spend more, the center has the largest single share in social affairs (42\%), economy (47\%) and transportation (49\%).

The exclusive competence of one government tier in a function (as indicated by the amount zero in Table 4) occurs only in a few cases. Otherwise, the division of powers and the principle of subsidiarity apply. Thus, general functions must be subdivided. For example, under the heading "social affairs" in general (see Table 4), the federal government plays an important but not dominant role (42\% of total social expenditures). The division of functions shows that the only domain where it plays a major role is social security (old-age pensions: $78 \%$, invalidity: $73 \%$ ). Surprisingly because one would think of a typical local public responsibility, "social housing" is more important at the federal level (52\%) than at the cumulated cantonal and communal levels $(38+10 \%)$ : this is explained mainly through the importance of initiative specific conditional grants paid to the cantons for this function. "Illness insurance" and the item "other social insurance" (mainly family allowances) are more important in the Cantons (with total of $56 \%$ and $59 \%$ respectively). Social aid is shared almost equally between the cantonal and communal layers and, though it is recognized as a typical local function in Switzerland, the federal government pays $16 \%$ percent of the total outlays. Communes assume almost exclusively the current costs of homes for elderly people (96 \%). This type of vertical assignment exists for almost all sub-functions (see also education in section 3.3.2 and environmental policies and health in section 3.3.3 for other examples); and again the division of expenditures varies from one canton to another.

$>$ Most of the countries in Central and Eastern Europe have followed a similar pattern of expenditure assignment since the early 1990s, with an incremental devolution of responsibilities toward the subnational levels. While municipal authorities play a more significant role in public 
service provision than provincial (regional) self-governments, the central government has retained important powers at the intermediate level through the territorial offices of line ministries. The central government and its deconcentrated territorial offices account for a considerable part of total public expenditures, leaving a very limited number of competences (and insufficient financial resources) to provincial governments. According to a plausible (but still tentative) explanation, the failure to vest newly elected provincial authorities with equally strong powers as those that the Soviet-type councils enjoyed during the socialist regime, has led to a "power vacuum" which was then gradually filled by the regional offices of central authorities (SZIGETI, 2004: 166). As Kandeva observes for the Balkans, "where there are representative elected bodies - such as district or county councils middle-tier governments become weaker and lose their former position as representatives of the municipalities and a superior level of local self-government coordinating the activities of the municipalities/communities in their territories. Where middle-tier governments have been created as territorial bodies of the central government, their powers in local governance increase, and consequently their controlling functions on the acts and actions of local self-government bodies increase as well" (KANDEVA, 2001: 32). In several countries (Czech Republic, Slovakia, Hungary, Albania), recent reforms aim to work against this phenomenon by the establishment of democratically elected self-governing regions at the intermediate level. However, in many cases both the central government and the municipalities are reluctant to cede a part of their expenditure competences to the new units. Consequently, regions have usually exclusive competence for developing the regional economy but only a marginal competence in almost all other policy areas. Since recently, the redefinition of territorial structures - and has imposed a growing pressure on decision-making bodies to reexamine the nature of intergovernmental fiscal relations.

$>$ Another challenge in the domain of expenditure assignment concerns the clarification of certain terms. It is often unclear whether the maintenance of public assets (hospitals, schools etc.) and new investments are included in the responsibilities of local governments or not. As the Swiss case demonstrates, the fact itself that some competences are shared between different government levels and others are exclusive does not compromise the efficiency of revenue assignment, as long as the law provides for a clear demarcation of competences to avoid inefficient duplications. The "labor division" between government levels in terms of public service production, once it is anchored in the law, creates an opportunity for fine-tuning expenditure policies at each level (the distribution of 
federal, cantonal and local responsibilities in environmental policies and education are two successful examples).

In Switzerland, the general trend in the division of responsibilities between the three government tiers has hardly changed for the last 30 years. When one particular function requires more resources compared to others, the growth of expenditures for that function runs almost parallel in the three levels. This is a very conservative situation. The various attempts to modify the existing constitutional division of tasks between the federal government and the Cantons have invariably and lamentably failed or produced insignificant results. ${ }^{15}$ Changes in the relative position of the three tiers may however happen, due essentially to external circumstances. During the economic crisis of the 1990s, for example, the federal government was first faced with higher unemployment. Thereafter, the Cantons were concerned with individual social aid because individual unemployment often persisted longer than the period of unemployment benefits. The cantonal share in the total amount of financing social aid was $40 \%$ in 1988, rose to $50 \%$ in 1999, to go down again to a $43 \%$ share in 2001 , although the law has not changed in the period. With $41 \%$, the local tiers has also assumed an important share of these expenditures, mainly in the form of contributions to cantonal expenditures or in an agency role in paying for social aid at standard levels fixed by the cantons. This experience will certainly shape the future of this particular task and its assignment at the federal (unemployment insurance) and the cantonal levels (individual social allowances), with the main responsibility being taken away from the communes.

\subsubsection{Subsidiarity}

In Switzerland, the fundamental principle in the assignment of tasks between the various levels of government is subsidiarity. Competencies are vested at the local level and can be transferred to the cantonal level only insofar that the lower level is no longer in a position to provide a service "efficiently". In most cantons, a constitutional amendment decided by popular vote or, at least, a law decided by the cantonal parliament, sometimes subject to referendum, is necessary. The same

15 See the following reports from ad hoc or special committees: Stocker Report 1966 on the revision of federal conditional grants and subsidies, the special reports for a new assignment of functions and responsibilities between the Confederation and the Cantons, first bunch of measures in 1971, second bunch of measures in 1978. These three reports did not result in any great change: the elephant gave birth to a mouse. In the current version of the proposal on the New Fiscal Equalization, the chapter concerning the (vertical and horizontal) reassignment of functions between the Confederation and the Cantons is fiercely debated. Radical changes have been washed out in order to prevent the rejection of the entire package in the 
principle applies to the relationship between the cantonal and federal levels. The transfer of any competence from the Cantons to the federal government requires an amendment to the federal Constitution, with a double majority vote of the people and the Cantons.

In reference to the concept of "subsidiarity", the key questions are not semantic, but start with (a) the definition and measurement of "efficiency"; (b) who decides when the provision of a local (decentralized) public service is no longer "efficient" and (c) at which level the responsibility should be "centralized". Opinions diverge about which "efficiency" criteria are appropriate for the organization (and reorganization) of functions within the three layers of government. ${ }^{16}$ Economies of scale, homogeneity of preferences, spillovers and congestion costs, are generally accepted as efficiency criteria (DAFFLON, 1992). But poorer governments argue that they are not able to score well enough for lack of sufficient budget resources, and so they ask for an increase in equalization payments.

As for the level of decision making, subsidiarity is a true "bottom-up" process with two inseparable elements in this principle:

(1) Competencies in the provision of public services belong to (or in terms of decentralization: "should be vested in") the lowest possible level in the fiscal hierarchy.

(2) It is the lowest level retaining the competence which decides and when it is no longer able to meet this particular responsibility and when and how it wants to hand it over to the next higher level.

The reference to "insufficient capacity" must be founded on sound economic arguments rather than on political or simple financial reasons. Transferring a function just for the fear of facing the electorate or the taxpayers is not reasonable. In case a commune is incapable to execute a specific public task, the first-best solution is not to transfer the task to the next higher tier but to examine the reasons why the available financial resources are insufficient. In this procedure, tax capacity as well as central government funding should be taken into account.

Education is a good example of how the principle of subsidiarity works. Table 4 shows that

popular vote which will probably take place in November 2004. See (DAFFLON, 2004).

16 See WALSH (1993: $32 \mathrm{ff}$.) for an overview of the normative arguments. 
under the general heading of education, the main responsibility lies at the cantonal level, with around $54 \%$ of total public outlays, followed by the local level (33 \%) and the Confederation (13\%). However, when various sub-functions are distinguished "bottom-up" within education, the image stands out in contrast. Kindergartens and public schools are principally in local hands (with respectively $63 \%$ and $57 \%$ ). For the public (primary and secondary) public schools, however, the communes have command mainly of the school buildings and the equipment. The teachers' salaries are predominantly paid at the local level, but according to cantonal standards. The Cantons also decide almost exclusively about the teachers' qualification, and the schools' programs (for the latter, sometimes in coordination with other Cantons within the Conference of the Cantonal Ministers of Education - see section 2.4 on cooperative federalism). Special schools are in some cantons local, and cantonal in others. Professional schools, teachers' schools, colleges and technical schools are predominantly if not exclusively placed at the cantonal level (the respective shares of total expenditures at the cantonal level are 71, 95 and $91 \%$ ). The federal government does not intervene very much. Except for the Federal Polytechnics, the 10 universities are cantonal, and partly financed by all the cantons through horizontal transfers shared according to the number of students and their cantonal usual residence, and through federal grants-in-aid. ${ }^{17}$

The subsidiarity principle implies that some degree of asymmetry in the provision of public services is acceptable. Yet it is difficult to assert whether this couple "subsidiarity - asymmetry" is an appropriate tool to recognize diversity, whether more differentiation is needed to attain a more or less harmonized quality in service delivery, or whether it will foster national integration or disintegration. Again, education and primary schools can serve as an illustration. Subsidiarity and asymmetry are certainly needed and useful if the objective is to preserve or promote cantonal historical and cultural diversity: Geneva and Zurich have neither the same approach nor the same tradition in teaching history, which in turn differs in a bilingual Canton like Valais or Fribourg. There is no objective necessity for uniformity. But the Cantons have to harmonize and partly succeeded in harmonizing their public school programs because of the increasing mobility (private and professional) of parents between the Cantons. This has been achieved and is operative through

17 For the year 2001, the "Compte d'Etat " of the Confederation (2001: 217) gives the following amounts for higher education: total expenditure amounts to 2,117 million Sfr. of which 1,365 million for the Federal Polytechnics in Zürich and Lausanne (65\%), 543 millions Sfr. for the cantonal universities (26 \%) and 209 million Sfr. for the High Professional Schools $(9 \%)$. 
intercantonal agreements. Yet, for example, the Cantons were unable to agree on the beginning of the school year (spring or autumn) to the point that it had to be fixed in the federal Constitution (article 62 in the 1999 Constitution) after a popular vote on September 22, 1985 with the double majority of voters and Cantons. Nowadays, teaching a second national language is at the crux of a difficult dispute. While the majority of the Cantons (and all the francophone Cantons or those with a French-speaking majority) advocates learning the second national language (German for the French-speaking, and vice versa) in first priority for reason of national cohesion, the Canton of Zurich decided in 2000 that in public schools, English rather than French will be given first priority for reasons of economic development and globalization. This has been criticized by many Cantons, including German-speaking ones, qualifying the decision an arrogant, disruptive and anti-confederal move. A federal parliamentary proposal is now on the way to oblige all the Cantons to consider another national language as the first priority. If it succeeds, this will be a further step toward creeping legal centralization.

$>$ All of the TEs in our analysis have ratified the European Charter of Local Self-Government (ECLSG), which means that, the subsidiarity principle (article 4 of ECLSG) has entered the political discourse on decentralization in Central and Eastern Europe, at least at a formal level. However, up to now the general acceptation of the principle has been limited to the component (1) of the definition above, which suggests that further efforts are needed in order to realize the bottom-up philosophy of this principle. In practice, its implementation proceeds relatively rapidly, while some important rules laid down in the Charter rest to be carried out in the next few years. As a general rule, the extent of subnational expenditure autonomy (the range of responsibilities and the modalities of change) is anchored in separate laws instead of the national constitution, and the amendment of these laws usually require only a simple majority. ${ }^{18}$ Transferring competences from one government tier to another is thus relatively easy, which makes subnational governments in principle vulnerable to sudden changes in their autonomy. The fact that the central government has the highest competence to decide about the horizontal sharing of expenditure powers provides an ample room for centralization even where subnational budget autonomy nominally exists (ADAMOVICH, 2003: 131).

18 An exception from this rule is the Local Government Act of Hungary which can only be amended with $2 / 3$ of the 
$>$ With regard to the transfer of responsibilities between subnational levels, Hungary provides a peculiar example of asymmetry According to the Act on Local Government, municipal authorities that do not feel able to finance a particular local task may transfer this task to the county level which is obliged to take it. Similarly, local governments of the county seats (i.e. major towns) may claim from the county level the downward transfer of any public institution (hospital, secondary school etc.) that is predominantly used by the residents of the town. In both cases it is the lowest level which decides when and how it wishes to hand it over to the higher level. Yet the subsidiarity principle is violated because the transfer of competences is based on a purely financial argument ("not able to finance"). As a result of these operations, public institutions with substantial infrastructural backlogs and low revenue-raising capacity get into the hands of the severely under funded counties which, for their part, hope for a rescue by the central government.

> This lesson teaches that the subsidiarity principle heavily depends on the correct design of revenue assignment: subnational governments must be empowered not only to execute public tasks and provide services of local interest, but also to raise sufficient funds (through taxation and participation in revenue-sharing models and grant programs) to cover their expenses.

\subsubsection{Centralization}

Table 3 gives the relative shares of each level of government in total public expenditures for the period 1970 to 2001 . Over the first period, these figures show almost stable proportions in the division of the public sector between the three layers. In the decade 1970-80, the proportions were $32 \%$ for federal expenditures, $39 \%$ for the Cantons and $28 \%$ for the communes. In 2000 , these percentages were respectively 32,40 and 27 , which represents a slight increase of the cantonal share to the detriment of the communes. In recent year, this trend has continuously accentuated: in 2001, for example, the respective share of the federal and cantonal tiers have consolidated around higher figures (respectively 33 and $41 \%$ ).

Although statistical data show that the relative shares of each tier have not much changed over the past 30 years, centralization creeps in the ways in which cantonal and communal governments 
perform. A distinction, described in the literature of fiscal federalism as "agency" versus "choice" models, may be useful for understanding the issue. In the last three decades, the federal government has increasingly confined itself to the issuing of framework laws and has delegated the implementation of nation-wide functions to the Cantons (which in turn often have transferred the tasks onto their communes) - which is the key characteristic of the "agency" model. One of the most impressive examples of this is the implementation of the federal environmental legislation. The federal government systematically issues normative legal rules (on the basis of art. 74 Cst.). The Cantons have to give impulses to their implementation, coordinate (public) provision and control the results. The communes are the executive agencies. The importance of local public expenditures in environment is clear from Tables 3 and 4 : it amounts to $61 \%$ of the public outlays for this function. Incentive conditional grants were distributed along the way, but this is no longer the case, as federal financial incentives were limited in time to the end of the 1990s. In Table 3, local public expenditures for water resources amount to $87 \%$ of total expenditure for this function; $69 \%$ for sewage and water purification plants and also $81 \%$ for waste collection and disposals. In these functions, local user charges should cover at least $70 \%$ of total current expenditures (including debt service for investments financed through borrowing), and ideally the total costs.

Health is another illustration of the "agency" role of the Cantons and the communes. The federal government is responsible for only a tiny proportion of health expenditures (around $1 \%$ ), mainly because health insurance is governed by a federal framework law. But the implementation of the law and the resulting costs remain in the hands of the Cantons (58 \%) and the communes (42\%), with obvious problems along this way (DAFFLON, 2002b).

At the lowest level, there is continuous dispute in the Swiss Cantons about the effective extent of autonomy in local public expenditures, first and foremost because no single measure of independence is appropriate (WOLMAN, 1990) so that the Cantons and the communes have divergent claims. A second difficulty in measuring a decentralization concept is that the fiscalfinancial relations between local and cantonal governments vary from one canton to another according to the 26 cantonal Constitutions. Yet, the general trend in all the Cantons has been that (1) under the constraint of a current balanced budget, the "choice" role of the communes has made more and more way for the "agency" role and (2) the change in the relative weight of the two roles is 
inversely related to the population size of the communes: larger municipalities have been better able to maintain a higher proportion of the "choice" role. In general one can say that probably around $1 / 4$ of total local current expenditures are made in response to standards set by higher government levels, 1/4 corresponds to ad hoc inter-communal institutions coordinating particular functions, which leaves about $1 / 2$ for current expenditures resulting from the own preferences of local residents (DAFFLON and PERRITAZ, 2000a).

Now then, what can be said about the tension between subsidiarity and centralization? There is no simple answer, but a very pragmatic approach and case by case solutions. However, two points deserve attention. First, a higher level of government cannot interfere so easily so as to impose its own idea of "efficiency" upon a lower level of government. The democratic procedure must be respected. The amalgamation of two or several communes is a good example: this has proved almost impossible on a compulsory basis with the argument that communes are often too small to perform correctly the functions assigned to them. And the voluntary amalgamation of communes responds to another logic than strict fiscal consideration (DAFFLON, 1998). Second, if a function needs more centralization, it will not be enacted by agencies of the higher-level government, but by lower-level governments acting as agencies. Thus, the communes will first organize in special "intercommunal" jurisdictions rather than giving up a function to the canton. And many federal standards are implemented by the cantons: law and justice are but two examples. In general, one finds no duplication of service precincts, federal agencies acting in the cantons, or cantonal agencies acting in the communes. The Communes act as implementation agencies of the canton or the Confederation, the cantons as agencies of the Confederation, most often with the capacity of performing more than required minimum service level if they want so, with the additional difficulty (from an analytical point of view) to distinguish what is the required standard and what is "choice" component.

$>$ Central and Eastern European transition economies have very similar concerns regarding the role of lower-level governments. Even though in the advanced reformer countries (Poland, Slovenia, Hungary, Latvia etc.) expenditures have been decentralized to a comparable degree as in Switzerland, the national regulation of the quantity and quality of local services is still prevalent, and central authorities control the implementation by means of their deconcentrated territorial units. The 
perceived need for uniformity partly derives from the relatively "underdeveloped" state of provincial/regional self-government, but also from the ambition to provide a standard minimum level of basic public services throughout the country. In the Balkans (Albania, Romania, Croatia and Macedonia) where real decentralization started with some delay compared to the rest of the Eastern European region, the presence of deconcentrated authorities and central government representatives (prefects) is even more visible, and their role in public service provision and local administration is almost as important as that of the elected self-governments.

> Similarly to the Swiss cantons and communes, subnational governments in TEs are also obliged to execute delegated tasks in "agency" position. In the Czech Republic, the recently adopted Act on the Regions (129 / 2000) introduces a category called "transferred sphere of activities" (in opposition to the "independent sphere of activities"), which is more or less equivalent with the concept of "mandatory responsibilities". In several countries, these mandatory responsibilities account for a substantial share of local and mid-level expenditures, as a consequence to central government endeavors to ensure an equal level of basic public services throughout the country. However, as the amount of conditional transfers agreed by the center do not always entirely cover the costs of these mandated tasks, local governments feel increasingly impelled to fill the gap with own-source revenues in order to meet the minimum service standards. The agency problem in TEs concerns thus not only on the expenditure side (redirecting local expenditures towards centrally dictated activities) but starts to erode the own-source revenues as well. The exact dimension of this problem is difficult to measure, since the nominal statistics on the share of subnational expenditures within total general government outlays tell little about which proportion of these subnational expenditures is spent on prescribed activities.

> Wrong responses on the part of central governments may involuntarily contribute to more centralization and to less responsibility at subnational levels. For example, the relatively small size of municipalities in TEs combined with a lack of willingness to cooperate often leads to budget hardships, as local governments cannot exploit potential scale economies. The central government's most common reaction to such fiscal bottlenecks - particularly if they jeopardize the provision of basic public services - is to make a bailout grant to the crisis-hit municipality. Obviously, the provider of the grant defines the conditions of how to use the money, thus interfering (though 
rationally) with the receiver's autonomy. Another inevitable corollary of the fragmentation of territorial structure and the unwillingness to cooperate is the shortage of skilled and specialized workforce and the lack of sufficient technical capacity, especially in the smallest municipalities. Such shortfalls in the administrative capacity are often addressed by transferring a part of the local government's competences to the territorial offices of the central government. In both cases there is creeping centralization, no matter how good the pursued intentions are. Of course, even if the expenditure and revenue assignment is perfectly designed, fiscal and technical bottlenecks will always occur, and hence a certain amount of intergovernmental grants will be inevitable. However, greater responsibility at subnational levels can only be achieved if local problems are addressed - whenever possible - with local solutions. Promotion of intercommunal cooperation and support to local capacity-building would be sustainable solutions for the above-mentioned problems. Moreover, the central government has less opportunity to encroach on local autonomy if bottleneck situations are not treated case by case but with a more integral approach. However, for such a strategy to be effective, it is essential that local politicians abandon the wrong habit (inherited from the era of centralized government) of accepting from the center any intervention that pledges to relieve them at least temporarily - from the bottleneck problem.

> To our view, the answer of the smallest Swiss communes to centralization efforts is worth some consideration. Through concluding various cooperation agreements and establishing special purpose districts on a voluntary basis, local communities in TEs, too, are likely to reach an acceptable level of efficiency in public service provision, thus proving that there is no need for the central level to withdraw any of the expenditure competences from the local level.

\subsection{Public revenues}

Funding local and provincial governments is a delicate issue in all Central and Eastern European countries where only a very few (if any) variables of the taxation formula are in the command of municipalities and the intermediate level. This leads to severe political conflicts between the various levels of government. It is therefore of importance to observe and analyze how public revenues are distributed in existing federations, particularly in Switzerland where the tradition of tax autonomy at the cantonal and local layers has been immovable for many decades. 
Between 1980 and 2001, there were 16 fiscal years for which the entire Swiss public sector (Confederation, Cantons and communes) registered a budget deficit. The balance of the accounts was positive in the period 1986-1989 and for the last two years reviewed, 2000 and $2001 .^{19}$ In 2001, public revenues amounted to 159,804 million Sfr. compared to 156,780 million Sfr. total expenditures. Only the federal level was in the red.

\subsubsection{General characteristics}

Details of public revenue sources are given in Tables 5 and 6 . Taxation is the most important single source of revenue for the three levels of government. The tax systems, the combination of various tax sources or the choice "taxes versus user charges", the definitions and measurements of the tax bases, and the rate schedules are variables that are largely in the command of the cantons. Though to a lesser extend, communes have a fairly large tax flexibility (definitions are given below). Consequently both layers determine the volume of financial resources at their disposal, thus the extent of their autonomy. The main characteristics of the fiscal-financial system are summarized below.

\section{Taxation}

$\checkmark$ Each level of government and each government within the same level has direct access to many, but at least two major revenue sources: at the federal level, direct taxation and VAT; at the cantonal level, direct taxation and revenue sharing + grants; at the local level, direct taxation and user charges. Direct access to taxes and user charges at the cantonal and local levels is important in order to maintain financial autonomy.

$\checkmark$ Based on VAT with an actual normal rate of $7.6 \%$, the main consumption and expenditure taxes are exclusive and belong to the federal level. Taxation on motor vehicle is cantonal; the communes can levy minor taxes on dogs, entertainment and games.

$\checkmark$ Direct taxation is a joint taxation of the Confederation (individual income + corporate profit), the

19 Without the deficit of the social security. In 1993, the highest deficit ever was 16,325 million SFr or 4.6 percent of GDP. This result did not respect one of the Maastricht criteria, namely that the total deficit of the public sector, including social security, should not exceed 3\% of GDP. But in the period between 1980 and 2001 this was the only year in which the Maastricht criterion was not met. 
Cantons and the communes (individual income and wealth + corporate profit and capital). For the Cantons and the communes, taxation of individual income and wealth and of corporate business profits and capital ("direct taxation") is the major single item of revenue sources (43 and $50 \%$ Table 6).

$\checkmark$ For the communes, user charges from local public utilities (mainly: water, sewage and purification plants, garbage collection) and indemnities (in total $26 \%$ ) provide the second most important revenue source. Together with the revenues from public property $(6 \%)$ they account for one third of total resources. However, these sources are limited. Revenues from immovable properties, whether public or private, are subject to the federal legislation on rent control. The total amount of user charges for one single function cannot exceed total costs owing to the jurisprudence of the Federal Supreme Court with regard to the quid-pro-quo rule in benefit taxation (i.e. user charges must be genuine cost-prices for public services, and not disguised taxes).

\section{Fiscal dependence}

At first glance, the Cantons and the communes have a rather low dependence on transfer payments: the Cantons receive less than $17 \%$ of their total revenues in the form of specific grants from the Confederation, and the communes receive less than $13 \%$ of their revenues from the Cantons. However, the reality behind this image is far from idyllic: a closer examination of the statistical series shows the nuances. Table 7 presents for each canton the proportion of total fiscal resources that is obtained through federal grant-in-aid and revenue sharing. This ratio can be considered as the degree of financial dependence of the cantons on external revenues.

Federal grants-in-aid are always specific, mostly conditional, and for some of them block grants based on performance output. They do really create a relation of dependence of the cantonal level toward the center since they are obtained for those functions only that are designated by the center and provided in the cantons.

Revenue sharing belongs to another category: those programs are written in the federal 
Constitution and are historically considered as a right for the Cantons to obtain part of specified federal tax yields. They always take the form of block payments, totally free in use at the cantonal level so that the constraint - or the loss of financial autonomy - is by far much more limited than it is the case with specific grants-in-aid.

In Table 7, the degree of financial dependence varies from around $9(+) \%$ for Basle-Town and Geneva to as much as $50 \%$ in the cantons Jura, Obwald and Uri. Such a range, from $9.4 \%$ to $51.2 \%$, might seem extremely large for an outside observer, but it represents a true image of the disparities that still exist in this country. Not surprisingly, there is a reasonable (though not very strong) inverse correlation between the cantons' national income per capita and their dependence on federal transfers $(r=-0.563)$. However, a simple regression equation consisting of this single variable would explain less than one-third of the total variance in financial dependence $\left(r^{2}=0.317\right)$. In order to learn more about what determines the degree of transfer dependence in a canton, several other factors must be examined in a multiple regression analysis.

Not only the degree but also the structure of dependence varies across the cantons. For example, the individual situations of the six richest cantons look like follows:

\begin{tabular}{c|c|c|c|c|c|c} 
& Zoug & Basle-Town & Zurich & Geneva & Nidwald & Basle-Land \\
\hline Financial capacity & 218 & 158 & 157 & 130 & 124 & 120 \\
\hline Financial dependence & & & & & & \\
- total & $26.7 \%$ & $9.4 \%$ & $18.5 \%$ & $9.8 \%$ & $35.8 \%$ & $13.7 \%$ \\
- grants-in-aid (GIA) & $9.3 \%$ & $6.4 \%$ & $12.5 \%$ & $5.6 \%$ & $29.1 \%$ & $10.1 \%$ \\
- revenue sharing (RS) & $17.4 \%$ & $3.0 \%$ & $6.0 \%$ & $4.2 \%$ & $6.7 \%$ & $3.6 \%$ \\
\hline Ratio RS / GIA & 1.88 & 0.48 & 0.48 & 0.74 & 0.23 & 0.35 \\
\hline
\end{tabular}

Financial capacity is given in points for a national average of 100 .

In Zoug, revenue sharing dominates because the yield of the FDT is particularly high: the ratio "revenue sharing to grants-in-aid" is 1.88 (Zoug is the only canton where RS > GIA). In Basle-Town 
and Zurich, this ratio is $48 \%$ but the financial dependence of Zurich is twice that of Basle-Town. In Geneva and Nidwald, financial dependence almost reaches the extremes with 10 and $36 \%$ respectively, yet the difference is essentially to be found not so much in the revenue sharing but in the high amount of federal grants transferred to Nidwald (29.1\%) in comparison to Geneva (5.6 \%). One cannot say that the patterns of financial dependence and of RS/GIA ratio are even for these six (richest) cantons.

$>$ In most TEs, the transfer dependence of provincial and local governments is more serious than in Switzerland. ${ }^{20}$ Grants from the central government in the subnational budgets account for a fairly high proportion of total revenues, up to $95 \%$ in Albanian municipalities. Subnational governments feel little motivated to raise own-source taxes as long as the central government continues to supply them with non-refundable grants (see the Box $\mathrm{C}$ for the role of tax revenues in local funding). This is true even though central funding for mandated expenditures often falls short of the subnational governments' expectations. Though an increasing number of local governments try to fill up their deficient budget with own-source revenues, their tax autonomy is still too often restricted to less productive taxes (the so-called "nuisance taxes" on dog-keeping, gambling etc.) The basic problem with these taxes is that collection costs might exceed revenues, as has been painfully perceived by most local governments. The imposition of tax rate ceilings and the uniformization of tax base calculation, as well as the restrictions on the range of local taxes are still common practice of central regulatory authorities. And even in countries with a relatively vast fiscal autonomy at subnational levels, regions and municipalities often refrain from introducing all types of taxes defined by the local tax law or exploiting the maximum rates, as they perceive that the national tax burden is already heavy enough and additional taxation at the local level would prompt taxpayers (residents and investors) to quit the jurisdiction. This problem cannot be resolved by simply granting a higher degree of tax sovereignty or tax flexibility to subnational levels with the tax competences of the center being unchanged. Rather, the center should cede a part of its tax room to the lower tiers of government. However, careful attention must be paid to how and when to enlarge local tax room. As central government funding for mandated functions is often insufficient, the leeway of subnational governments to decide and finance own preferences is very little anyway. For this reason, the

20 Surprisingly, however, in some of the decentralized unitary countries of Eastern Europe (e.g. Czech Republic, Poland) the share of grants in the subnational budget - in the average of the years 1995 to 2000 - is smaller than in some West- 
reassessment of central funding for mandatory tasks should precede the introduction of new measures for the enhancement of local tax effort.

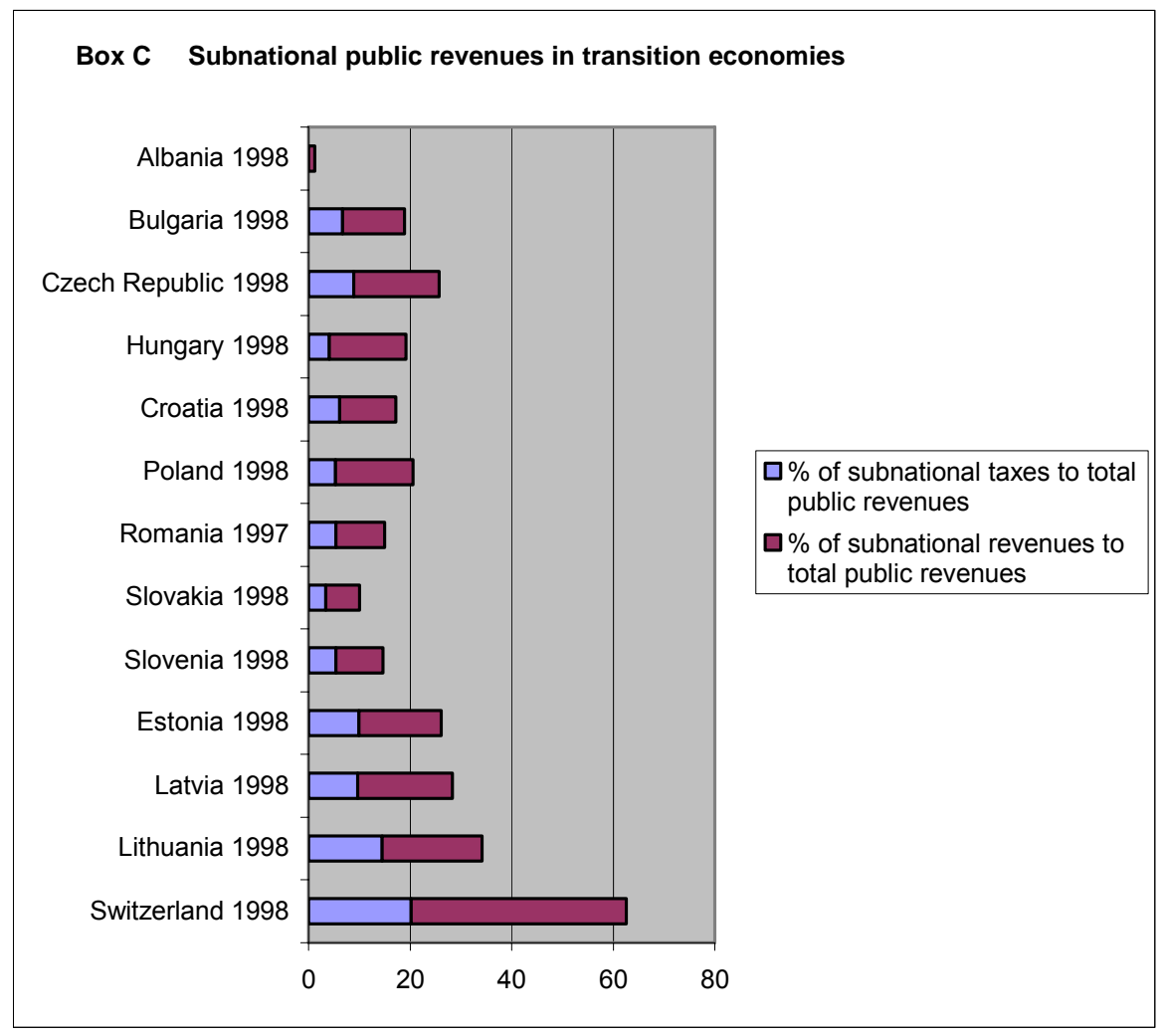

Source: (WORLD BANK, 2004)

\subsubsection{Tax sovereignty}

There is a long and apparently endless debate in fiscal federalism literature about the conceptual definition of tax sovereignty. Tax sovereignty concerns both the ability of a government to decide which taxes it should invent and raise, the direct access to taxation and the management of taxes. Let us summarize the general setting in the simplified formula:

$$
\mathrm{T}=\mathrm{t} \times\left[\mathrm{B}-\left(\mathrm{D}_{1}, \mathrm{D}_{2}, \mathrm{D}_{3}, \ldots \mathrm{D}_{\mathrm{i}}, \ldots \mathrm{D}_{\mathrm{n}}\right)\right] \times\left(\mathrm{K}_{\mathrm{Fed}}+\mathrm{K}_{\text {canton }}+\mathrm{K}_{\text {commune }}\right)
$$


where $T$ revenue from a tax

$\mathrm{t}$ the tax rate schedule

B the gross tax base

D the possible deductions from the tax base

$\mathrm{K}$ the annual coefficient aiming at a balanced (current ?) budget.

Referring to this formula, the extent of tax sovereignty can be measured in the following sequences of choice :

a) the use of the ability-to-pay principle (taxes) versus benefit principle (user charges);

b) the object of taxation, implicit in $[\ldots]$ in the formula above;

c) the circle of taxpayers (including the definition of the taxpaying unit);

d) the computation of the tax bases (for example, for the taxation of income: the definition of gross income $[B]$, and the adjustments to taxable income, specific deductions and exemptions) $\left[D_{i}\right]$;

e) the tax rate schedules [t], including the amount of deductions and exemptions in the previous letter $\left[\mathrm{D}_{\mathrm{i}}\right]$;

f) the annual coefficient of taxation $\left[K_{j}\right]$;

g) collecting the taxes;

h) the procedure in case of tax dispute.

- Full tax sovereignty comprises letters a) to h) in the list above.

- Partial tax sovereignty exists where a government can decide a) and some but not all items listed between b) and e).

- Tax flexibility means that a government can at least decide on the coefficient of taxation (f) but has no access to defining the kind of taxes it can raise.

- Compulsory taxation qualifies taxation where a government has no choice over a) to f) and must raise taxes (or user-charges) according to the regulations set by a higher level of government.

In Switzerland, tax sovereignty lies primarily in the Cantons and secondarily in the Confederation to such an extent that it is stated in articles 128 to 134 of the 1999 Federal Constitution. The 
Cantons' freedom to structure and frame their proper tax system and to decide the tax burden is limited in three ways:

(i) Cantons are bound by three articles in the federal Constitution which allocate indirect taxation (VAT in article 130 Cst., and special consumption taxes in article 131 Cst.) exclusively to the center and another that forbid taxes in the form of tariff barriers (art. 133 Cst.) which could impede the free movement of goods between the Cantons;

(ii) The Federal Supreme Court's jurisprudence that prohibits, in particular, double taxation or unjustified tax rebates (in a very restrictive sense);

(iii)Two federal laws on the federal direct tax and on the harmonization of direct taxation by the cantons and the communes that were passed on 14 December 1990. These laws were enforced on 1 January 1993, granting however an eight-year transition period to the cantons in order for them to adjust their own tax laws accordingly. This period ended on 31 December 2000. Again, the impingement on the Cantons' tax sovereignty is limited: harmonization concerns only the definition of the tax base $B$ in the formula above) and the list and definitions of the possible deductions from the tax base (the $D_{i}$ in the formula) but not the amounts of each of them.

In this situation of joint taxation, tax sovereignty means that there are 27 laws, with obvious problems of competition, coordination and harmonization. The autonomy of the communes to manage their finance varies from one canton to another. In principle, the Cantons regulate the financial room for maneuver of their communes by establishing budget principles, uniform accounting model, taxation rules and debt limits. Local governments have limited tax sovereignty in that they can choose between ability-to-pay taxes and user charges where appropriate. They are however tied to the tax system of their Canton. For many taxes, local governments have only tax flexibility: they must apply the cantonal laws and limit their decision to an annual coefficient of taxation $\left[\mathrm{K}_{\text {commune }}\right]$ in percentage of the Canton's taxes. Local taxation is also compulsory for a limited number of taxes. If a commune chooses to raise user charges and fees, it can also define the main components (object of taxation, circle of users and thus payers, computation of the user charge base and the tariff), however within the limits set by case law of the Federal Supreme Court (KNAPP, 1982: 358-364). 
Thus, Switzerland applies a double institutional regime, one for the Cantons (facing the central State) and one for the communes (facing the Cantons). At the cantonal level, the gross tax base and the list of deductions ( $B$ and $D_{i}$ in the formula above) are identical, but the tax rate schedule and the actual amounts of $D_{i}$ are decided freely by each cantonal parliament. At the local level, the tax regime is that of tax flexibility, very close to piggyback; the commune can only decide about the necessary coefficient $\mathrm{K}$ to balance their budget. At these two levels, the only restriction to excessively large differences in direct taxation is the mobility of tax payer units, and tax competition.

> TEs in Central and Eastern Europe show a wide variety in the degree of fiscal sovereignty of subnational entities. In Bulgaria and Macedonia, all parameters of local taxes and user fees are determined by national law; in Hungary, Estonia and Romania, these parameters are kept within limits. Both approaches risk to erode nominal tax rates in case of high inflation rates. Croatia has a system of partial tax sovereignty for local levies and tax flexibility for piggybacking the central government's income tax. The Czech Republic and some other countries have introduced a mixed system, ensuring full sovereignty for local user charges but severely restricting local freedom for "ability-to-pay"-type taxes. Compared to municipal governments, provincial and regional governments in Eastern Europe are seldom allowed to influence their tax revenues, and even where they have a formal autonomy in budgetary issues (e.g. the voivodships and counties in Poland), they are often denied the right to levy own taxes. Instead they receive a share from central tax revenues and other grants, and they are eventually free to lease or sell their own properties. If any lesson for TEs can be drawn out of the Swiss double regime, it is that tax flexibility can effectively guarantee the fiscal autonomy of subcentral government tiers. Nevertheless, the partial tax sovereignty granted to the cantons has high administrative and compliance costs, it is not neutral and accounts for significant disparities and inequalities in the fiscal treatment of taxpayers. These problems have not yet been solved. Tax flexibility, and not partial tax sovereignty, should be therefore the fiscal code for TEs.

The objectives of tax flexibility are: 
(1) to enable each level of government and each government within a level, to finance its own budget independently and according to its own need. This includes the capacity of financing public services in response to the preferences of their own electorate (the "choice" model) as well as those expenses which correspond to minimum standard (merit) goods and services set by a higher level of government (the "agency" model), net of conditional grants.

(2) to decide redistributive policies in selecting ability-to-pay or benefit taxation.

However, different tax coefficients create two problems. One is tax competition. The other one is the necessity of an equalization policy (between the center and the Cantons; and within a Canton, between the Canton and the communes) because of disparities in the tax burden which often do no correspond to objective differences in the functions of cantonal and local governments, but to their geographical position. ${ }^{21}$

$\checkmark$ It is clear that, with the indices of cantonal and communal corporate profit tax varying from as low as 58 points in Zoug (Table 8, column 4) to 124.1 in Geneva, corresponding to a ratio of 2.32, there is room for interjurisdictional competition for attracting business activities. Yet, as ROSSI and DAFFLON (2004) demonstrate, tax competition has not helped poorer cantons - for various reasons - to attract a substantial volume of economic activities, rather it has provoked a "race to the bottom". In any case, the relative position of the cantons have changed very little over the long run, those with higher fiscal capacity being more able to reduce their tax rate or to grant tax facilities to new or developing business activities.

$\checkmark$ The general picture is very much contrasted also for the individual taxpayers. The relative burden from income taxation varies from as low as 49.5 points in Zoug to a maximum of 132.4 points in Jura. That is, taxpayers in the canton Jura pay on average 2.7 times the income tax that the average resident in Zoug does, and it is impossible to confirm that a resident of Jura also receives 2.7 times as much public service than what is provided in Zoug - on the contrary if one

21 For a presentation and discussion of the actual equalization system between the Confederation and the cantons, see (DAFFLON, 2004); between one canton and its communes, see (DAFFLON et al., 2004) which includes bibliographical references to various cantonal case studies. For a general European overview of the equalization at the local level, see (FÄRBER G. and OTTER N., 2003). 
refers to Table 1 and the discussion about the economic position of the cantons. This is probably one of the most pernicious problems of Swiss federalism and a high price indeed for tax sovereignty.

$>$ Tax competition is not yet an issue in TEs, since lower level governments in the countries reviewed are normally not authorized to set their own tax rates, or their chosen rates are bound to move between legal maximum and minimum limits (an exception from this rule is Croatia). However, as soon as the central government introduces tax flexibility so that subnational levels may thenceforward determine their own tax coefficients, tax competition will become presumably arise. A high interjurisdictional mobility will result in a considerably tough tax competition, which will raise the need for horizontal tax coordination. At present, the interjurisdictional mobility of the population is not significant, since people are traditionally "rooted to the soil" and the housing market is still underdeveloped. However, as markets grow and the costs of relocation decrease, the fiscally induced migration of labor may become more intensive.

Tax competition has its harmful effects in Switzerland, the most important of which is probably the overall decline in cantonal and local tax revenues, which results in an excessive reduction of public expenditures in policy areas that are relatively little appreciated by private enterprises. Through decreased spending on health care, education, housing etc., tax-cutting trends reduce the welfare of the citizens. Up to this date, tax competition in Switzerland has probably brought more harm than benefit, therefore transition countries should be cautious about adopting the Swiss model of tax sovereignty.

\subsubsection{Direct access to many revenue sources}

An important characteristic of fiscal autonomy is direct access to many (fiscal) sources. In Table 5 , several finance sources are listed respectively for the federal government, the Cantons and the communes.

Direct access to a number of diversified tax or non-tax sources secures regular annual receipts 
compared with a situation where a government can rely on one tax only. It enables a better distribution of the fiscal burden and avoids exasperating particular categories of taxpayers in case of higher fiscal needs. This can also be understood in the view of the low dependence of the Cantons on transfer payments from the federal government and of the communes on transfer payments from the Cantons. This is observed in Table 6 from the percentage of the various categories of revenue for the three levels of government.

$\checkmark \quad$ In 2001, the net "tax / grant" ratio for the cantons, a measure introduced by KING (1984: 185) which measures the proportion of tax revenues to intergovernmental transfers in the budget of intermediate level governments, was 1.55 for the totality of the 26 cantons, whereas the "own resources / total transfers" ratio was 2.31. These results suggest a relatively large independence of cantonal finance on federal transfer payments. The usual interpretation is that the Swiss Cantons do not depend much on federal payments and enjoy a fairly high degree of fiscal autonomy. However, the individual position of the cantons is widely different: the values of the "tax revenues / total transfers" ratio range from 0.32 (Obwald) to 6.07 (Geneva), while the "own resources / total transfers" ratio starts at a similar level, 0.56 (Jura), of and reaches its maximum at 9.55 (Basle-Town).

$\checkmark$ The communes received only $16 \%$ of their revenues from the Cantons in the form of revenue sharing for $3 \%$ and grants for $13 \%$ (Table 6 ). Although these proportions were about 5 points lower for the communes in the early eighties (and for the cantons as well), the actual figures do not represent a very high degree of financial dependence compared to other OECD countries. And in any case, these proportions - viewed from the revenue side - contrast with the degree of centralization in public expenditures, which is much higher because the agency role of decentralized governments has gained in importance during the last decade compared to the "choice" model.

$>$ The proportion of shared revenues within local and provincial/regional budgets in Central and Eastern Europe varies from 10-15 \% in Hungary and 18-25 \% in Poland and Slovakia to a third or even a half of the local budget in Bulgaria, Slovenia and Estonia. Both Bulgaria and the Czech Republic are particular cases insofar as the administration of major taxes is centralized and the 
entire revenue is transferred to subnational governments; however, the latter cannot influence the tax rates and the tax base nor introduce any further taxes. In Albania, shared revenues account for only 2 to $3 \%$ of the municipal budget (and districts receive no revenue shares at all), while the rest is financed through direct grants from the central state. Shared revenues are unknown in Croatia, too, but here the bulk of the subnational budget consists of own taxes and surtaxes. A "compromise solution" is observed in Macedonia where a mix of central government grants and independent local revenues make up $95 \%$ of the local budget, and revenue sharing has never been introduced. As is illustrated by the Swiss (and the Croatian) example, subnational dependence on shared revenues may be substantially decreased if self-governments gain important access to alternative revenue sources such as local taxes and user charges.

As long as the distribution formulas are stable and guaranteed by the constitution or a law that cannot be changed every year during the budgeting procedure, revenue sharing may be a reliable source of funding for subnational authorities. In a number of TEs (such as Albania, Romania, Hungary, Bulgaria and Lithuania), revenue shares are fixed neither in the constitution nor in the public finance act. Instead, they are revised on an annual basis, depending on the actual political and economic pressures faced by the central government (WETZEL, 2001: 27). This obviously "kills" the beneficial effect of sharing the revenues over a wide range of different taxes, a policy which has been so fruitful in Switzerland.

Finally, flaws in the design of revenue-sharing tend to exacerbate existing horizontal fiscal disparities in TEs. The distribution of tax receipts according to the principle of origin (a frequent practice in TEs) is particularly responsible in this matter, as it contributes to the conservation of existing inequalities in wealth and economic activities across jurisdictions (SLUKHAI, 2002). Becoming increasingly aware of this negative side effect, several TEs (like the Czech Republic, Hungary and Romania) are currently planning to introduce (or have introduced) a fiscal equalization component in their revenue-sharing schemes Though these "experimental" equalization measures are often blamed to be unstable, non-transparent and badly targeted, undoubtedly they mark a major milestone on the way to a full-fledged fiscal decentralization. 


\subsubsection{Tax administration}

Tax administration belongs to the fiscal sovereignty of decentralized government (see 3.4.2 above): in principle, each level of government and each government within a same level may have its own tax administration. However, this is not the case in Switzerland. The federal government has no tax administration for the federal direct tax (FDT): the Cantons have a legal obligation to collect the FDT on individual income and corporate profits, along with their own taxes. They also participate in managing the federal withholding tax and stamps duties. However, since there are 26 cantonal tax laws and as many tax administrations and no tutelage of the federal government over State and local tax administration, there exist 26 ways of managing cantonal taxes and the FDT. In order to gain economies of scale in the tax administration and coherence in the tax practice, many formulas exist for cooperation between the three tiers of government. Nevertheless, the present system of managing and collecting direct taxes being far from optimal, propositions and arguments are raised from time to time in the favor a "flat rate" direct tax that would circumvent these difficulties.

In addition, since the powers of the State tax administrations are limited to the territorial area of the State to which they belong, whereas economic activities may spill over cantonal limits, a decentralized tax administration creates problems and conflicts. These have been solved in the first place by negotiations between the Cantons, eventually (and more often) through the jurisprudence of the Federal Supreme Court. Secondly, a federal law on the harmonization of cantonal direct taxation has been enforced on 1 January 1993 to introduce some order in the Cantons' taxation for neutrality and equity reasons. Since 1 January 2001, the cantons have had to adapt their own tax legislation to a common unique framework, where $B$ and $D_{i}$ in the taxation formula are defined by the center, but the maximum amount of each $D_{i}$ and "t" are left to the individual cantons to decide.

At the local level, no such difficulties exist. In most cases, the communes can only decide annual tax coefficients for the various accessible tax sources, but have no access to defining the kind of tax they raise, nor its calculation or its rate schedule: it is a "take it or leave it" situation. In many cantons, the communes can contract with the cantonal tax administration to collect communal taxes. $^{22}$

22 In the Canton of Fribourg, the cost for a commune is $1.5 \%$ of the net tax revenues. The cantonal tax administration 


\subsubsection{Tax coordination}

\section{Vertical coordination}

Vertical coordination concerns the assignment of tax authority to the various levels of government. It should be clear which jurisdiction is entitled to tax which items from which taxpayer. Attention must be given to the geographical distribution of tax yield. A good tax under subcentral authorities should have a tax base that is widely and evenly distributed throughout the country (KING, 1984: 210-211). In addition, one can say that the general objectives of vertical tax coordination:

(i) stable and predictable revenue sources at the three levels;

(ii) high proportion of own resources in total cantonal and communal revenues;

(iii) sufficient tax room at the cantonal and communal levels, and

(iv) efficient decentralized taxation and accountability.

These conditions are fulfilled in the Swiss case. Referring to Table 7, one can also add that in Switzerland vertical coordination is obtained:

Partly through the attribution of exclusive tax sources to each level of government according to the doctrine of the separation of sources. This is clear for consumption and expenditure taxes where there is no overlapping of the tax bases between the Confederation, the Cantons and the communes.

$\checkmark$ On the other hand, for "direct" taxation, personal income and corporate profits ${ }^{23}$ are jointly taxed at the three levels. The vertical apportionment between the three levels of government is rather complex and often left implicit. It is obtained in two ways: a moderate taxation at each level so that no single government exhausts the entire tax capacity; and, the assessment of priority, first to the Cantons, then to the communes and lastly to the Confederation. It has been traditionally admitted for direct taxation that the federal share should not exceed one fourth of the total (Table

collects communal taxes on the basis of the communes' own coefficient $\mathrm{K}$ and acts for the commune in all aspects of tax litigation. The tax proceeds are paid to the commune on a monthly base. 
8). Minimum taxable income at the federal level should be higher than in the Cantons and the tax rate schedule more progressive. Yet, the Cantons receive back some $30 \%$ of the federal direct tax (FDT) in the form of revenue sharing, of which $13 \%$ is affected to inter-cantonal fiscal equalization.

Note also that Switzerland has a particular characteristic: vertical tax coordination is written in the federal Constitution. Following art. 196 al. 13 of the transitory provisions of the 1999 Cst., the FDT may be levied until the end of 2006 only. The consequence is that, some years before this limit, the federal government must justify the further necessity of levying a direct tax at the central level in concurrence with the Cantons and the communes, and explain its motives. ${ }^{24}$ The decision to continue to levy a FDT necessitates the double majority of voters and Cantons, which is a powerful mean for the Cantons to obtain compensatory advantages, notably in the equalization policy.

$\checkmark$ With the enforcement of the value-added tax (VAT) on 1 January 1995, and with it, the extension of expenditure taxation to services, the most orthodox federalists claim that the joint attribution of direct taxation to the Confederation and the Cantons should end. The argument is that the overall burden of indirect (consumption) taxes is still lower in Switzerland than in most other European countries. This gives a freedom of maneuver which should be used to reduce the direct tax burden which, combined to social security contributions, is higher than average. For some, there should be a crystal-clear order in taxation under the slogan: "VAT is federal / direct taxation is cantonal". Opponents argue that the abolition of the FDT will set back income redistribution through ability-to-pay taxation because the tax rate progressiveness of the FDT is higher than in any canton. In addition, the abolition would create difficulty in the federal-cantonal equalization policy.

$\checkmark$ Vertical coordination between the Cantons and their communes is secured because, as explained in section 3.4.2, local governments have no sovereignty on these matters, but only tax

23 The federal direct tax on business capital has been suppressed by the law of October 10, 1997, from 1998 onwards. 24 On December 9, 2002, the Federal Council has published a message concerning the "New Fiscal Regime 2007" in which it proposes to abolish any existing temporal limitation on the collection of the FDT and the value-added tax (see Feuille fédérale No. 8, 4 mars 2003, p. 1390). In March 2004, both chambers of the Parliament approved the proposal. The final 
flexibility. The most debated question is whether local governments can taper at this source in priority, to the detriment of the cantonal tiers. The usual solution is that communal tax coefficients are subject to an upper limit fixed in the cantonal law in proportion to cantonal taxes (for example: in the Canton of Fribourg, this limit is fixed at a maximum level of $125 \%$ of the cantonal tax).

\section{Horizontal coordination}

Horizontal coordination serves to apportion tax competencies and the tax yields among the jurisdictions at the same level where the tax base has its origin in several communes or cantons. In Switzerland, this has been obtained through the jurisprudence of the Federal Supreme Court. Two objectives have been pursued: avoidance of double taxation, and, preventing that taxpayers with taxable activities in more than one jurisdiction avoid the progressiveness of the tax rate schedules through geographical splitting of the tax base. Although the technical rules are rather intricate (DAFFLON, 1986: 32-36), horizontal coordination applies itself along the following general guidelines:

- the income tax is entirely paid in the canton and the communes of residence, ${ }^{25}$

- any income obtained in other jurisdictions is assessed in the jurisdiction of residence according to the rules of the jurisdiction of residence (and not the rule of the jurisdiction where the income has been gained);

- immovable property is taxed in the jurisdiction where it exists and according to "in situ" rules;

- when corporate business takes place in several jurisdictions, the yields of the profit and capital taxes are distributed between those jurisdictions according to financially measurable components of the activity (for example: turnover, the volume of sales, total insurance premiums for insurance companies).

decision will be taken by the voters in an obligatory referendum.

25 This has been confirmed by the Federal Supreme Court early in 1999 in a dispute between the cantons of Geneva and Vaud concerning commuters working in Geneva but resident in Vaud who had received income tax assignment from the canton of Geneva (see the Order of the 1st Public Law Court of October 27, 1999, Canton Vaud v. the Republic and Canton of Geneva: Official Bulletin of the Federal Supreme Court, 125 I, p. 458-474). 


\section{BUDGET POLICY}

The Swiss Cantons have their own Constitutions, independent power over their budgets and their own financial resources and, above all, they have the power of taxation. Cantonal autonomy in the area of fiscal policy contrasts with the budget principles and the rules of taxation to which member States in other federations are subject. Legislative authorities at the federal level, in the 26 Cantons and in every single municipality must decide the budget (current + capital) before the beginning of the year and, of course, keep books recording revenues and expenditures. Since the mid 1980s, budget and bookkeeping techniques have been harmonized. Annual budgets as such do not give a legal base for expenditures and taxation. Each item in the current as well as in the capital budgets must be founded on particular laws that have been debated separately in parliament and enforced prior to the budget discussion.

The federal Constitution does not impose budget principles on the Cantons. There is no federal constraint on deficit financing, except that all tiers of government have no access to borrowing from the Central Bank. The main external limitation on budgetary sovereignty of the Cantons is intrinsically competition with other cantons: if a canton pursues an inefficient fiscal policy with a poor cost-benefit relationship, it will price itself out of the market. Individuals and firms will move "à la Tiebout" to another canton ("exit", in Hirschman's terminology); or the voters or some groups of them will use initiatives and referenda in order to obtain a modification of the "public goods / tax" mix in comparison to that of other cantons ("voice"). Competition is even more important at the local level, particularly between communes in the same urban agglomeration.

\subsection{Budget orthodoxy}

The fairly extensive autonomy of cantonal and local governments for their finance is not unlimited. The are also internal limitations in cantonal Constitutions or laws. Two rules are generally respected, at the level of the Cantons in their own financial laws, and in the communes under cantonal supervision (DAFFLON, 2002a). 
$\checkmark$ The first rule is concerned with the requirement of a more or less balanced budget for providing goods and services. Due to financial regulation, for most local and cantonal governments it is quite difficult to run or to accumulate deficits in their (current) budgets. If a large budget deficit occurs, taxation would have to be increased. In many cantons, the amortization must not only be recorded in the book, but also correspond to an effective installment of the loans. At the communal level, if a local authority would not follow this rule, the cantonal government might decide to raise the annual coefficient of taxation in place of the commune. ${ }^{26}$ In general, the Cantons apply the "golden rule": local current revenues net of current expenditures are sufficient to serve the debt interest and bear the running costs of past and new investments. Whether this rule includes the effective annual reimbursement of the debt on a pay-as-you-use basis (for capital expenditures financed by borrowing) varies from one canton to another. This also necessitates a clear line between current and capital expenditures and, of course, separation of the current from the capital budget. Again, the definition is not identical from canton to canton: in particular with regard to the possibility (i) to transform capital expenditures into current outlays through leasing contracts to shortcut limitation, if any, or (ii) through outsourcing of certain expenditures to external budgets not accounted for by the public sector.

$\checkmark$ The second rule concerns borrowing and debt limitation. Public debt is allowed in many cantons only for financing capital expenditures, and if the local and/or cantonal government has the financial capacity to pay the interest and amortization of the debt out of its current budget. The rates of amortization are fixed according to the kind of investment and its possible length of use (pay-as-you-use finance). This of course requires a distinction between the current budget, which must be balanced, and the capital budget, which can be financed by borrowing.

These two more or less strict requirements express the principle of accountability or budgetary responsibility. They must be viewed in the perspective of the cantonal and communal financial

26 For example, in September 1994, the State Council (the executive government) of canton Berne imposed on the commune of Berne (the capital city of the Canton and also the federal city) an increase of the tax coefficient from a multiple of 2.2 to 2.4 of the cantonal direct taxes levied in the commune. The reason was that the electorate of the commune had rejected for the third time the 1994 budget, which presented a deficit and required for balance an increase of taxation. In Fribourg, the Canton controls on a yearly basis the books and the public debt of the communes. It intervenes if the current account is not balanced or if amortization of the debt and the effective reimbursement of loans are not sufficient according to legal minimum rates. Cantonal intervention takes several forms, but it can go so far as to impose a higher tax coefficient to the commune at fault in order to restore its financial situation. 
autonomy and a large access to own revenue sources as described above. On the one hand, cantonal and local governments have a fairly large (though diminishing) amount of autonomy to decide and offer public services, and direct access to taxation. On the other hand, it is expected that these governments will act in a responsible way and will finance without excess borrowing what they are asked to produce, either by law ("agency") or in response to their electorate's own demands ("choice"). This is definitely a classical approach to fiscal federalism (TOLLISON and WAGNER, 1986). The interests of the public debt of the cantons in 2001 represented on average $4 \%$ of total cantonal outlays; and $6 \%$ for the communes (Table 4 ).

Finally, there is growing evidence for the effectiveness of financial referenda in restraining the size of the public sector, on the one hand, and in reinforcing budget discipline, on the other (see section 2.3).

In Central and Eastern Europe, borrowing by subnational governments is still a relatively new phenomenon, and regulations and practices vary significantly across the region (SWIANIEWICZ, 2004). Several countries (such as Estonia, Slovakia and Romania) apply the "golden rule", nevertheless, as capital and current budgets are usually not separated, the implementation of this rule is rather difficult to control. In countries like the Czech Republic, Hungary or Poland, there is no prohibition on borrowing for operational purposes, yet most of the contracted loans serve capital investments. Maximum limits on borrowing and debt service have been introduced in several - but not all - TEs. Despite the high diversity of existing rules, the borrowing practice of Eastern European subnational governments is generally prudent, which is also reflected in the relatively modest average share of debt revenues in the local and regional budgets. Budget discipline and accountability have recently become core issues in the Eastern European local public finance, particularly because the perspective of a future accession to the euro zone compels the government sector to reduce public debt and deficit levels. Given the need for a continuous development of public infrastructures, there is a clear scope for a wider use of borrowing at decentralized levels. This, however, requires not only a well-developed credit market but also stable rules on borrowing and debt service, and predictable revenue sources for subnational governments. Better implementation and monitoring, as well as improved information systems are only a few challenges for the years to come. Examples of "best practice" can be learnt not only from Switzerland, but from 
other European countries as well (DAFFLON, 2002a).

\subsection{Macroeconomic policy}

The decentralization of government functions raises problems for macroeconomic control at the national level. This is because cantonal and communal accountability involves the access to own revenue sources together with the right of the Cantons and the communes to borrow. Uncontrolled access to capital markets and mismanagement of the budgets by cantonal and local government could jeopardize the efforts, if any, to stabilize the economy. For this reason, so the textbook argument runs, central government ought to have some monitoring or control power. However, one must distinguish whether the assignment of responsibilities and revenues to the cantonal and communal tiers is in balance and regular, or volatile and subject to strong cyclical variation. In the first case, control can be restricted to the golden rule, that borrowing is allowed only for infrastructures, and the time-path of capital investment. In the second case, borrowing may be needed not only for investment, but also to compensate for cyclical variation in the budget (higher social assistance expenditures, with less revenue, in downwards cyclical turn).

Nevertheless, the actual decentralized public finance may be somewhat distant from the textbook theory. Stabilizing tax adjustments is a mere conjecture in the Swiss situation: the electorate has to vote the tax law at the cantonal level, or the tax coefficient at the local level: while it may accept variation in taxation, whether to restore a balanced current budget or for new investments, it is unlikely to do so just for macroeconomic reasons. In addition, the time path required for such a decision is probably foreign to upward or downward changes in the macroeconomic trend.

On the side of public expenditures, the economic classification in Table 9 gives an interesting first insight into the capacity of the center to manage macroeconomic policy. At the federal level, current and capital grants account for $52 \%(45+7)$ of total expenditures, whereas revenue sharing, written in the Constitution, amounts to $12 \%$. Expenditures for personnel and interest payment have a share of $11 \%$ and $7 \%$ respectively. This means that about $82 \%$ of the total budget is spent on expenditure categories that are very difficult, if not impossible, to modify in the short term for macroeconomic purposes. Consumption (9\%) and own investments (2\%) reach hardly $11 \%$ of the total federal budget. This is by no means sufficient for any kind of functional 
finance.

At the cantonal level, the picture is not much better: here, too, expenditure categories that are rigid on the short term are personnel (37\%), debt interest $(4 \%)$, revenue sharing $(2 \%)$, and grantsin-aid in the current and capital accounts $(34+3 \%)$, in total $81 \%$ of cantonal public expenditures. As a consequence, merely one fifth of the total cantonal public expenditures (constituting the categories of "consumption" and "own investment") can be swiftly adapted to stabilization policy objectives - with the additional restriction on single investments discussed below.

Not surprisingly, one finds that the communes spend much more on consumption $(21 \%)$ and investment $(12 \%)$ than the other government tiers: it amounts to roughly $33 \%$ of their total expenditures. This suggests that, in quantitative terms, local governments would be the most suitable tier to implement macroeconomic policy. However, local governments are small open economies not interested in engaging themselves in such policies for fear of spillover effects.

The actual distribution of expenditure responsibilities between the three layers of government in Switzerland, and the very nature of these outlays, do not mean that any macroeconomic policy through fiscal instruments is impossible, at least from a conceptual point of view. Yet, because of the difficulty to act on personnel expenditures and transfers in the short term, one must recognize that any macroeconomic policy cannot be driven by and at the center only. It requires some form of consensus between the three government tiers and vertical cooperation. This is not an easy matter because (twenty-six) regional and (around 2880) local interests are potentially divergent. In particular, more and more investment projects require important financial resources and long term planning: when such a project is ready to be voted, it is doubtful whether any government will accept to postpone it for macroeconomic reason. And inversely, it is not so easy to accelerate a project for macroeconomic reason without taking the time to present a detailed investment program or rushing it through the parliamentary process not respecting democratic procedure. A canton or a commune may be very reluctant to abandon or postpone an investment for the sake of a central coordinated macroeconomic policy. This explains also why the fiscal and budget policy plays only a limited role in stabilization (AYRTON, 2002), compared to the position of the monetary authorities through the Swiss National Bank. 
At present, subcentral government tiers in TEs are not strong enough to put through their individual interests against the macroeconomic policy efforts of the center. Local investment and consumption decisions seldom interfere with the cyclical movements in central macroeconomic policy. This means that during recession, the center can easily gear the economy through stimulating local consumption and investment, whereas in periods of economic expansion, measures for reducing the aggregate demand generally do not clash with any expansionary efforts of subnational governments. However, as decentralization proceeds, the budgetary autonomy of subnational authorities will be expanded, and the central governments' efficiency in macroeconomic management may be reduced.

\section{CONCLUSIONS}

Although the government structure and hence the intergovernmental fiscal relations in Switzerland are quite different from what can be found in the transition economies of Central and Eastern Europe, Switzerland still sets a valuable example in various domains of fiscal federalism. Remarkable similarities between Switzerland and Eastern Europe can be observed in the degree of fragmentation of the territorial structure and in the importance of horizontal disparities. By way of conclusion, we briefly formulate 12 lessons that TEs may draw from the Swiss experience:

1. Enlarging the scope for direct democracy (an increase in the number of referenda, the introduction of fiscal policy issues on the agenda etc.) is likely to inspire citizens' trust and interest in local politics. Direct participation in policy-making will encourage local economic development and enhance social and individual welfare.

2. In consideration of the growing economic pressure on national budgets (especially due to the Maastricht requirements of convergence with the euro-zone), local authorities should not count on bailout grants being continuously paid by the central government in the long term. Problems of inefficiency in local public service provision should instead be solved through inter-communal cooperation.

3. Through spontaneous cooperation based on mutual economic interests, small and financially 
weak municipalities can effectively fend off any potential central government intervention aimed at the withdrawal of certain local expenditure competences.

4. The Swiss case provides evidence that policies aiming at a higher degree of fiscal devolution are not necessarily frustrated by extreme interregional disparities. Various systems of cooperation between government units and the attenuation of excessive disparities through well-designed fiscal equalization schemes may compensate for the difficulties arising from a widely heterogeneous structure of government.

5. An in-depth analysis of the relative position of democratically elected governments and bureaucratic/administrative authorities at the intermediate level is a pre-requisite for sound intergovernmental fiscal relations in every TE. Even if the elected regional bodies in Central and Eastern Europe are not supposed to enjoy similarly wide autonomy as the Cantons in Switzerland, a clear delineation of their competences vis-à-vis the central government and its territorial units is indispensable.

6. Once regions are empowered to assume considerable expenditure and revenue autonomy, they may become an important counterweight to central government and start playing a significant role in the socio-economic development of the country.

7. The Swiss example shows that expenditure-sharing does not affect the efficiency of revenue assignment as long as the law provides for a clear demarcation of competences between government tiers to avoid inefficient duplications.

8. The principle of subsidiarity can best be safeguarded when subnational competences are anchored either in the constitution or in a law that requires a 2/3 majority for being amended, and if local and regional units have sufficient access to financial resources.

9. The Swiss double regime of cantonal and local taxation suggests that tax flexibility can effectively guarantee the fiscal autonomy of subnational governments. In contrast, the partial tax sovereignty of the Cantons has high administrative and compliance costs; it is not neutral and may lead to severe inequalities between taxpayers.

10. However, once overall tax flexibility is introduced for the subnational government tiers in TEs, inter-jurisdictional tax competition is likely to emerge. Central governments will need to formulate reasonable policies for horizontal tax coordination in order to offset potentially harmful 
competition, since - as the Swiss example demonstrates - the downward spiral of tax rates may lead to a drop in subnational government expenditures and thus reduce the overall welfare of citizens.

11. With regard to the fiscal discipline at the lower levels, the Swiss case shows that there is no need for a central administrative control on local borrowing. However, it is essential to edict clear rules and sanctions of non-compliance, and to implement them rigorously. In Switzerland, the combination of a golden rule with direct democratic instruments has proven to be successful -in the cantons where it is implemented - in limiting the size of government as well as in rationalizing collective decisions and enhancing the efficiency of public investments by means of a democratic debate.

12. Finally, the transition from a deconcentrated socialist system of governance to genuine devolution of powers makes it relatively difficult for the center to coordinate macroeconomic policy at the national level. The major challenge is to find out to what extent the central government may interfere with the affairs of subcentral authorities without hurting the autonomy of the latter. Both macroeconomic stabilization instruments as well as the budgetary coordination between government tiers need to find their proper limits. In Switzerland, the federal government has abandoned the use of fiscal instruments in macroeconomic policy: stabilization is ensured by the Swiss National Bank. 


\section{References}

ADAMOVICH, I. B. (2003), Entstehung von Verfassungen: Ökonomische Theorie und Anwendung auf Mittelund Osteuropa nach 1989, doctoral dissertation, University of Fribourg.

AYRTON, R. (2002), L'impossible politique budgétaire, l'Etat fédéral face aux turbulences économiques, Presses polytechniques et universitaires romandes, Collection Le Savoir Suisse, vol. 3, Lausanne.

BENZ, M. and A. STUTZER, (2002), Are Voters Better Informed When They Have a Larger Say in Politics? Working Paper No. 119, Institute for Empirical Economic Research, University of Zurich.

BIRD, R. M., R. D. EBEL and Ch. WALLICH (1996), "Fiscal decentralization: From command to market", in: Bird, R. M., R. D. Ebel and Ch. Wallich (eds.), Decentralization of the Socialist State: Intergovernmental Finance in Transition Economies, World Bank Regional and Sectoral Studies, Avebury, pp. 1-67.

DAFFLON, B. (1986), " Fédéralisme, coordination et harmonisation fiscales : étude du cas suisse", Recherches économiques de Louvain, vol. 52/1, pp. 3-43.

DAFFLON, B. (1992), "The assignment of functions to decentralized government: from theory to practice", Environment and Planning C: Government and Policy, vol. 10, pp. 283-298.

DAFFLON, B. (1995), "Fédéralisme et solidarité: étude de la péréquation en Suisse", publication de l'Institut du Fédéralisme, Université de Fribourg, Études et colloques no. 15.

DAFFLON, B. (1998), "Les fusions de communes dans le canton de Fribourg (Suisse): analyse socioéconomique", Annuaires des collectivités locales, GRALE et CNRS, Litec, Paris, pp. 125-166.

DAFFLON, B. (ed.), (2002a), Local Public Finance in Europe: Balancing the Budget and Controlling Debt, Edward Elgar, Cheltenham.

DAFFFLON, B. (2002b), "Fédéralisme et sécurité sociale en Suisse: le cas de l'assurance maladie ", in Cattoir, Ph., Ph. De Bruycker, H. Dumont, H. Tulkens and E. Witte (eds), Autonomie, solidarité et coopération, Quelques enjeux du fédéralisme belge, Editions Larcier, Bruxelles, pp. 175-209.

DAFFLON, B. (2004), "Federal-cantonal equalisation in Switzerland: an overview of the reform in progress", Public Finance and Management, forthcoming (Fall 2004).

DAFFLON, B. et al. (2004), La péréquation intercommunale dans le canton de Fribourg : bilan et enjeux, BENEFRI Centre d'études en économie du secteur public, Série : études et rapports, No. 1, Fribourg.

DAFFLON, B. and S. PERRITAZ (2000a), L'influence de la taille des communes sur leur degré d'autonomie budgétaire: Présentation d'une méthode d'analyse et application aux communes fribourgeoises, Working Paper No. 335, Faculty of Economics and Social Science, University of Fribourg. http://www.unifr.ch/finpub/f-pub recherches.htm

DAFFLON, B. and S. PERRITAZ (2000b), Federal-Cantonal Equalisation in Switzerland: An Overview of the Present System and Reform in Progress, Working Paper No. 356, Faculty of Economics and Social Science, University of Fribourg, updated in November 2003, http://www.unifr.ch/finpub/fpub recherches.htm.

DAFFLON, B. and J. RUEGG (2001), Réorganiser les communes, créer l'agglomeration, Editions Universitaires Fribourg, Collection Economie et Gestion, Vol. 4.

DELLA SANTA, M. (1996), Dalla Collaborazione alla Fusione: Analisi degli aspetti economici, istituzionali e sociologici del Comune, doctoral dissertation, University of Fribourg, Vico Morcote.

FÄRBER, G. and N. OTTER (eds.), (2003), Reforms of Local Fiscal Equalisation in Europe, Speyerer Forschungsberichte 232, Forschungsinstitut für Öffentliche Verwaltung, Speyer, Germany.

FEKETE É., M. LADOS, E. PFEIL and ZS. SZOBOSZLAI, (2002), "Size of Local Governments, Local Democracy and Local Service Delivery in Hungary", in: Swianiewicz, P. (ed.), Consolidation or Fragmentation? The Size of Local Government in Central and Eastern Europe, OSI/LGI Budapest, pp. 31100.

FLEINER, T. and L. R. BASTA FLEINER (2000), "Federalism, Federal States and Decentralization", in: Basta Fleiner, L. R. and T. Fleiner (eds.), Federalism and Multiethnic States: The Case of Switzerland, Institut du 
Fédéralisme Fribourg Suisse, Helbing \& Lichtenhahn, Basel, pp. 1-40

FREY, B. (2003), "Direct Democracy for Transition Countries", Journal for Institutional Innovation, Development and Transition, published by IMAD, Vol. 7, pp. 42-59.

FREY, B. and R. EICHENBERGER (1999), The New Democratic Federalism for Europe, Edward Elgar, Cheltenham.

IMF, (2003a), Government Finance Statistics Yearbook, Washington DC.

IMF, (2003b), International Financial Statistics Yearbook, Washington DC.

IVANOV, S., G. TCHAVDAROVA, E. SAVOV and H. STANEV (2002), "Does Larger Mean More Effective? Size and the Function of Governments in Bulgaria", in: Swianiewicz, P. (ed.), Consolidation or Fragmentation? The Size of Local Government in Central and Eastern Europe, OSI/LGI Budapest, pp. 167217.

KANDEVA, E. (2001), "Introduction to Comparative Local Government in Central and Eastern Europe: A Balkan Perspective", in: Kandeva, E. (ed.), Stabilisation of Local Governments, LGI/OSI Budapest, pp. 1940.

KING, D. (1984), Fiscal Tiers : the Economics of Multi-level Government, Allen and Unwin, London.

KIRCHGÄSSNER, G. and W. POMMEREHNE (1990), Evolution of public finance as a function of federal structure: a comparison between Switzerland and the Federal Republic of Germany, mimeograph, International Institute of Public Finance, 46th Congress, Brussels.

KIRCHGÄSSNER, G., L. FELD and M. SAVIOZ (1999), Die direkte Demokratie: Modern, erfolgreich, entwicklungs- und exportfähig, Helbing and Lichtenhahn Verlag Vahlen AG, Basel.

KLING, J., V. NIŽŇANSKY and J. PILAT (2002), "Separate Existences Above All Else - Local SelfGovernments and Service Delivery in Slovakia", in: Swianiewicz, P. (ed.), Consolidation or Fragmentation? The Size of Local Government in Central and Eastern Europe, OSI/LGI Budapest, pp. 101-166.

KNAPP, B. (1982), Précis de droit administratif, Editions Helbing et Lichtenhahn, Bâle et Francfort.

KNAPP, B. (1986), "Etapes du fédéralisme suisse", in: Handbuch Politisches System der Schweiz, Vol. 3: Föderalismus, Haupt Verlag, Bern.

LACINA, K. and Z. VAJDOVA (2000), "Local Government in the Czech Republic", in: Horváth, M. T. (ed.), Decentralization: Experiments and Reforms, LGI/OSI Budapest, pp. 255-295.

LADNER A., D. ARN, U. FRIEDERICH, R. STEINER and J. WICHTERMANN (2000), Gemeindereformen zwischen Handlungsfähigkeit und Legitimation, Forschungsbericht, Forschungsprojekt des Schweizerischen Nationalfonds im Rahmen des Schwerpunktprogramms "Zukunft Schweiz", IOP Verlag, Bern.

MARCOU, G. (2002), "Regionalization for Development and Accession to the European Union: A Comparative Perspective. Hungary - Lithuania - Poland - Slovakia - Ukraine", in: Marcou G. (ed.) Regionalization for Development and Accession to the European Union: A Comparative Perspective, OSI/LGI Budapest, pp. 11-27.

MASTNY, V. (1998), The Historical Experience of Federalism in East Central Europe, SIPA Working Papers, Columbia University, New York.

NOVARESI, N. (2001), Discipline budgétaire: étude de l'influence du référendum financier et des règles d'équilibre budgétaire sur les finances publiques des vingt-six cantons suisses, BENEFRI Centre for Studies in Public Sector Economics, University of Fribourg, Switzerland, Série: Thèse de doctorat.

OECD (2003), OECD Economic Outlook - Special Focus on Fiscal Policy and Institutions, Vol. 2, No. 74, December.

OECD (2004), OECD Economic Outlook, Vol. 1, No. 75, June.

OLSON, M. (1969), "The principle of 'fiscal equivalence': the division of responsibilities among different levels of government", American Economic Review, 49, pp. 479-487. 
POMMEREHNE, W. (1978), "Institutional approaches to public expenditures: empirical evidence from Swiss municipalities", Journal of Public Economics, 9, pp. 255-280.

POMMEREHNE, W. and F. SCHNEIDER (1978), "Fiscal illusion, political institutions and local public spending", Kyklos, 31/3, pp. 381-408.

PUJOL, F. (2000), L'incidence des préférences sur la discipline budgétaire, unpublished doctoral dissertation, Department of Economics, University of Geneva, May 2000.

ROSSI, S. and B. DAFFLON (2004), "Tax competition between subnational governments: theoretical and regional policy issues with reference to Switzerland", in: Controversies on Fiscal Policy: Proceedings of the 2003 Workshop of the Research Network on Alternative Macroeconomic Policies, Berlin, 24-25 October 2003, forthcoming.

SLUKHAI, S. (2002), Shaping Fiscal Equalization Techniques in Transitional Countries, paper prepared for the 10th NISPAcee Annual Conference, Krakow, Poland, April 25-27, 2002.

SWIANIEWICZ, P. (2004), "Comparing International Experiences: Emerging Markets of Local Borrowing?", in: Swianiewicz, P. (ed.), Local Government Borrowing: Risks and Rewards: A Report on Central and Eastern Europe, OSI/LGI, Budapest, pp. 385-424.

SZIGETI, E. (2004), "A magyar megyerendszer és regionalizmus vázlatos történeti áttekintése" [A brief historical overview of the county system and regionalist movements in Hungary], Magyar Közigazgatás, 54(3), pp. 164-171.

TOLLISON, R. D. and R. E. WAGNER (1986), "Balanced Budgets and Beyond", in Buchanan, J. M., C. K. Rowley and R. D. Tollison (eds.), Deficits, Basil Blackwell, Oxford, pp. 374-390.

Von HAGEN, J., (2003), "Fiscal Federalism and Political Decision Structures", in Blindebacher, R. and A. Koller (eds.), Federalism in a Changing World - Learning from Each Other, McGill-Queen's University Press, Montreal, pages 373-394.

WALSH, C. (1993), "Fiscal federalism: an overview of issues and a discussion of their relevance to the European Community", in: European Economy: Reports and Studies, No. 5, European Commission, DG for Economic and Financial Affairs, Luxembourg.

WETZEL, D. (2001), Decentralization in the Transition Economies: Challenges and the Road Ahead, The World Bank, Washington DC.

WOLMAN, H. (1990), "Decentralization: What It Is and Why We Should Care", in: Bennett R. J. (ed.), Decentralization, Local Governments, and Markets: Towards a Post-Welfare Agenda, Clarendon Press, Oxford, pp. 29-41.

WORLD BANK (2004), Fiscal Decentralization Indicators, Washington D.C., retrieved July 8, 2004, from http://www1.worldbank.org/publicsector/decentralization/fiscalindicators.htm

ZIMMERMANN, H. (1987), "Föderalismus und Einheitlichkeit der Lebensverhältnisse", in: Schmidt, K. (ed.), Beiträge zu Ökonomischen Problemen des Föderalismus, Duncker und Humblot, Berlin. 
Table 1a: Some general indicators of the Swiss Cantons, 2001

\begin{tabular}{|c|c|c|c|c|c|c|c|}
\hline \multirow[b]{2}{*}{ Canton } & \multirow[b]{2}{*}{$\begin{array}{l}\text { Number of } \\
\text { communes }\end{array}$} & \multirow[b]{2}{*}{$\begin{array}{c}\text { Surface } \\
\text { area }\left(\mathrm{km}^{2}\right)\end{array}$} & \multicolumn{2}{|c|}{ Population } & \multicolumn{3}{|c|}{$\begin{array}{l}\text { National Income in the Cantons } \\
\text { (NIC) }\end{array}$} \\
\hline & & & $\begin{array}{c}\text { Total } \\
\text { (in ‘000s) }\end{array}$ & $\begin{array}{c}\text { Density } \\
\left(1000 \mathrm{p} / \mathrm{km}^{2}\right)\end{array}$ & $\begin{array}{l}\text { Total mill. } \\
\text { Sfr }\end{array}$ & $\begin{array}{l}\text { SFr per } \\
\text { capita }\end{array}$ & $\begin{array}{c}\text { Per capita } \\
\text { variation } \\
(\%) 1980 \\
2001\end{array}$ \\
\hline 1 & 2 & 3 & 4 & 5 & 6 & 7 & 8 \\
\hline Zoug & 11 & 239 & 100.9 & 422 & 7,191 & 71,733 & 22.3 \\
\hline Basle-Town & 3 & 37 & 186.7 & 5,046 & 11,978 & 63,002 & 14.6 \\
\hline Zurich & 171 & 1,729 & 1228.6 & 711 & 72,504 & 58,540 & 20.8 \\
\hline Geneva & 45 & 282 & 414.3 & 1,469 & 20,763 & 49,969 & 1.3 \\
\hline Nidwald & 11 & 276 & 38.6 & 140 & 1,989 & 53,189 & 34.1 \\
\hline Basle-Land & 86 & 518 & 261.4 & 505 & 13,415 & 51,853 & 28.1 \\
\hline Schaffhouse & 34 & 299 & 73.4 & 245 & 3,593 & 49,322 & 27.4 \\
\hline Argovie & 232 & 1,404 & 550.9 & 392 & 26,655 & 48,808 & 23.3 \\
\hline Schwyz & 30 & 908 & 131.4 & 145 & 6,235 & 47,862 & 38.4 \\
\hline Vaud & 384 & 3,212 & 626.2 & 195 & 30,272 & 47,748 & 21.7 \\
\hline Thurgovie & 80 & 991 & 228.2 & 230 & 9,639 & 42,357 & 22.0 \\
\hline Soleure & 126 & 791 & 245.5 & 310 & 10,425 & 42,927 & 16.8 \\
\hline Saint-Gall & 90 & 2,026 & 452.6 & 223 & 19,356 & 42,926 & 23.1 \\
\hline Glaris & 29 & 685 & 38.3 & 56 & 1,796 & 47,249 & 5.8 \\
\hline Tessin & 245 & 2,812 & 311.9 & 111 & 11,181 & 36,665 & 12.0 \\
\hline Grisons & 212 & 7,105 & 185.7 & 26 & 7,782 & 41,339 & 9.8 \\
\hline Lucerne & 107 & 1,494 & 350.6 & 235 & 14,319 & 41,136 & 23.9 \\
\hline Uri & 20 & 1,077 & 35 & 32 & 1,468 & 42,966 & 37.4 \\
\hline Berne & 400 & 5,959 & 947.1 & 159 & 38,796 & 40,697 & 12.3 \\
\hline $\begin{array}{l}\text { Appenzell } \\
\text { Rh.-Ext. }\end{array}$ & 20 & 243 & 53.2 & 219 & 2,273 & 42,934 & 25.8 \\
\hline $\begin{array}{l}\text { Appenzell } \\
\text { Rh.-Int. }\end{array}$ & 6 & 173 & 15 & 87 & 588 & 39,940 & 26.6 \\
\hline Neuchâtel & 62 & 803 & 166.5 & 207 & 6,645 & 39,858 & 10.6 \\
\hline Fribourg & 226 & 1,671 & 239.1 & 143 & 9,055 & 37,748 & 16.4 \\
\hline Obwald & 7 & 491 & 32.7 & 67 & 1,151 & 35,427 & 9.0 \\
\hline Jura & 83 & 839 & 69.1 & 82 & 2,263 & 33,616 & 6.4 \\
\hline Valais & 160 & 5,225 & 278.2 & 53 & 9,692 & 35,309 & 10.1 \\
\hline Switzerland & 2880 & 41,289 & 7261.1 & 176 & 341,024 & 46,970 & 17.6 \\
\hline
\end{tabular}

Source: "Annuaire statistique de la Suisse 2003", OFS, Berne (columns 2-8); "Finances publiques en Suisse 2001" 
Table 1b: Some general indicators of the Swiss Cantons, 2001

\begin{tabular}{|l|l|l|l|l|l|}
\hline & \multicolumn{5}{|c|}{ Public finance in the Cantons } \\
\hline \multicolumn{1}{|c|}{ Canton } & Expenditures & \multicolumn{1}{|c|}{ Revenues } & $\begin{array}{c}\text { Balance of } \\
\text { revenues and } \\
\text { expenditures }\end{array}$ & $\begin{array}{c}\text { Public sector } \\
\text { size } \\
\text { (\% of NIC) }\end{array}$ & $\begin{array}{c}\text { Per capita } \\
\text { public } \\
\text { expenditures }\end{array}$ \\
\hline Zoug & 9 & 10 & $11=(10)-(9)$ & $12=(9):(6)$ & $13=(9):(4)$ \\
\hline Basle-Town & 801,478 & 848,188 & 46,710 & 11.15 & 7,943 \\
\hline Zurich & $9,951,705$ & $4,010,686$ & 58,981 & 32.99 & 21,166 \\
\hline Geneva & $6,760,559$ & $10,557,020$ & 750,704 & 13.53 & 7,982 \\
\hline Nidwald & 303,288 & $3,611,547$ & $-149,012$ & 32.56 & 16,318 \\
\hline Basle-Land & $2,206,120$ & $2,209,127$ & 11,534 & 15.25 & 7,857 \\
\hline Schaffhouse & 537,041 & 561,180 & 24,139 & 16.45 & 8,440 \\
\hline Argovie & $3,418,568$ & $3,516,202$ & 97,634 & 12.95 & 7,317 \\
\hline Schwyz & 696,032 & 756,413 & 60,381 & 11.16 & 6,205 \\
\hline Vaud & $6,039,208$ & $6,169,875$ & 130,667 & 19.95 & 9,297 \\
\hline Thurgovie & $1,369,366$ & $1,468,142$ & 98,776 & 14.21 & 6,001 \\
\hline Soleure & $1,516,856$ & $1,538,637$ & 21,781 & 14.55 & 6,179 \\
\hline Saint-Gall & $3,292,982$ & $3,465,658$ & 172,676 & 17.01 & 7,276 \\
\hline Glaris & 345,854 & 328,772 & $-17,082$ & 19.26 & 9,030 \\
\hline Tessin & $2,526,297$ & $2,604,943$ & 78,646 & 22.59 & 8,100 \\
\hline Grisons & $1,787,282$ & $1,803,620$ & 16,338 & 22.97 & 9,625 \\
\hline Lucerne & $2,497,665$ & $2,692,765$ & 195,100 & 17.44 & 7,124 \\
\hline Uri & 446,238 & 454,333 & 8,095 & 30.40 & 12,750 \\
\hline Berne & $7,912,635$ & $7,698,561$ & $-214,074$ & 20.40 & 8,355 \\
\hline $\begin{array}{l}\text { Appenzell Rh.- } \\
\text { Ext. }\end{array}$ & 356,556 & 369,984 & 13,428 & 15.69 & 6,702 \\
\hline $\begin{array}{l}\text { Appenzell Rh.- } \\
\text { Int. }\end{array}$ & 112,976 & 109,365 & $-3,611$ & 19.21 & 7,532 \\
\hline Neuchâtel & $1,583,524$ & $1,577,809$ & $-5,715$ & 23.83 & 9,511 \\
\hline Fribourg & $2,091,144$ & $2,101,742$ & 10,598 & 23.09 & 8,746 \\
\hline Obwald & 269,580 & 278,191 & 8,611 & 23.42 & 8,244 \\
\hline Jura & 747,343 & 742,905 & $-4,438$ & 33.02 & 10,815 \\
\hline Valais & $2,558,289$ & $2,400,310$ & $-157,979$ & 26.40 & 9,196 \\
\hline Switzerland & $\mathbf{6 3 , 9 3 4 , 9 0 2}$ & $\mathbf{6 5 , 1 9 0 , 7 9 7}$ & $\mathbf{1 , 2 5 5 , 8 9 5}$ & $\mathbf{1 8 . 7 5}$ & $\mathbf{8 , 8 0 5}$ \\
\hline & & & & & \\
\hline
\end{tabular}

Source: A.F.F., Berne, 2003 (columns 9-10): 65, 67, 93, 95; La Vie économique, Revue de politique économique, Berne, 3-2004:108-109 
Table 1c: Some general indicators of the Swiss Cantons, 2001

\begin{tabular}{|l|l|l|l|l|l|}
\hline & \multicolumn{5}{|c|}{ Public finance in the communes } \\
\hline \multicolumn{1}{|c|}{ Canton } & Expenditures & \multicolumn{1}{|c|}{ Revenues } & $\begin{array}{c}\text { Balance of } \\
\text { revenues and } \\
\text { expenditures }\end{array}$ & $\begin{array}{c}\text { Public } \\
\text { sector size }\end{array}$ & $\begin{array}{c}\text { Per capita } \\
\text { public } \\
\text { expenditure }\end{array}$ \\
\hline Zoug & \multicolumn{1}{|c|}{14} & \multicolumn{1}{c|}{15} & $16=(15)-(14)$ & $17=(14):(6)$ & $18=(14):(4)$ \\
\hline Basle-Town & 632,777 & 611,690 & $-21,087$ & 8.80 & 6,271 \\
\hline Zurich & 9,747 & 97,075 & 3,328 & 0.78 & 502 \\
\hline Geneva & $1,447,955$ & $10,348,272$ & 670,717 & 13.35 & 7,877 \\
\hline Nidwald & 155,504 & $1,593,229$ & 145,233 & 6.97 & 3,495 \\
\hline Basle-Land & 991,313 & 155,289 & -215 & 7.82 & 4,029 \\
\hline Schaffhouse & 382,148 & 382,443 & $-5,790$ & 7.39 & 3,792 \\
\hline Argovie & $2,320,604$ & $2,370,864$ & 295 & 10.64 & 5,206 \\
\hline Schwyz & 676,318 & 694,022 & 17,704 & 10.85 & 5,147 \\
\hline Vaud & $3,864,335$ & $4,008,278$ & 143,943 & 12.77 & 6,171 \\
\hline Thurgovie & $1,032,204$ & $1,063,767$ & 31,563 & 10.71 & 4,523 \\
\hline Soleure & $1,218,075$ & $1,222,211$ & 4,136 & 11.68 & 4,962 \\
\hline Saint-Gall & $2,547,667$ & $2,640,314$ & 92,647 & 13.16 & 5,629 \\
\hline Glaris & 228,399 & 224,486 & $-3,913$ & 12.72 & 5,963 \\
\hline Tessin & $1,696,984$ & $1,756,715$ & 59,731 & 15.18 & 5,441 \\
\hline Grisons & $1,384,129$ & $1,360,739$ & $-23,390$ & 17.79 & 7,454 \\
\hline Lucerne & $1,934,316$ & $1,948,160$ & 13,844 & 13.51 & 5,517 \\
\hline Uri & 120,061 & 125,368 & 5,307 & 8.18 & 3,430 \\
\hline Berne & $6,365,795$ & $6,593,738$ & 227,943 & 16.41 & 6,721 \\
\hline Appenzell Rh.- & & & & & \\
\hline Ext. & 244,954 & 247,613 & 2,659 & 10.78 & 4,604 \\
\hline $\begin{array}{l}\text { Appenzell Rh.- } \\
\text { Int. }\end{array}$ & 39,255 & 41,485 & 2,230 & 6.68 & 2,617 \\
\hline Neuchâtel & $1,376,516$ & $1,345,846$ & $-30,670$ & 20.72 & 8,267 \\
\hline Fribourg & $1,079,495$ & $1,025,716$ & $-53,779$ & 11.92 & 4,515 \\
\hline Obwald & 142,808 & 149,719 & 6,911 & 12.41 & 4,367 \\
\hline Jura & 446,362 & 437,890 & $-8,472$ & 19.72 & 6,460 \\
\hline Valais & $1,609,692$ & $1,602,710$ & $-6,982$ & 16.61 & 5,786 \\
\hline Switzerland & $\mathbf{4 1 , 7 0 9 , 0 0 9}$ & $\mathbf{4 3 , 0 3 3 , 1 6 2}$ & $\mathbf{1 , 3 2 4 , 1 5 3}$ & $\mathbf{1 2 . 2 3}$ & $\mathbf{5 , 7 4 4}$ \\
\hline & & & & & \\
\hline & & & & & \\
\hline
\end{tabular}

Source: "Finances publiques en Suisse 2001"; A.F.F., Berne, 2003 (columns 14-15): 65, 67, 93, 95; La Vie économique, Revue de politique économique, Berne, 3-2004:108-109 
Table 2: Financial capacity of the cantons, 2000-2001

\begin{tabular}{|c|c|c|c|c|c|c|}
\hline Cantons & $\begin{array}{c}\text { NIC per } \\
\text { capita } \\
1996 / 97 \\
(\times 1.5) \\
\end{array}$ & $\begin{array}{c}\text { Inverse of } \\
\text { tax burden } \\
1995-1998 \\
(x 1)\end{array}$ & \begin{tabular}{|c|} 
Tax \\
revenues \\
$1996 / 1997$ \\
$(x$ 1.5) \\
\end{tabular} & $\begin{array}{l}\text { Expenditure } \\
\text { requirements } \\
\text { (x } 1)\end{array}$ & $\begin{array}{l}\text { Weighted } \\
\text { average }\end{array}$ & $\begin{array}{l}\text { Total } \\
\text { index }\end{array}$ \\
\hline 1 & 2 & 3 & 4 & 5 & 6 & 7 \\
\hline Zurich & 125.15 & 118.22 & 126.56 & 108.95 & 120.95 & 157 \\
\hline Berne & 88.5 & 83.25 & 84.99 & 94.18 & 87.53 & 66 \\
\hline Lucerne & 88.82 & 87.75 & 83.36 & 102.09 & 89.62 & 72 \\
\hline Uri & 86.81 & 113.89 & 81.17 & 73.61 & 87.89 & 67 \\
\hline Schwyz & 97.49 & 118.71 & 94.2 & 85.49 & 98.35 & 96 \\
\hline Obwald & 77.47 & 89.06 & 70.99 & 76.76 & 77.7 & 40 \\
\hline Nidwald & 115.81 & 128.85 & 105.77 & 83.38 & 108.92 & 124 \\
\hline Tessin & 84.06 & 96.67 & 100.53 & 85.96 & 91.9 & 78 \\
\hline Zoug & 158.32 & 142.23 & 161.02 & 96.63 & 143.57 & 218 \\
\hline Fribourg & 84.63 & 70 & 78.09 & 97 & 82.21 & 52 \\
\hline Thurgovie & 86.31 & 102.42 & 89.4 & 110.44 & 95.28 & 87 \\
\hline Bâle-Ville & 141 & 89.93 & 129.6 & 111.1 & 121.39 & 158 \\
\hline Bâle-Campagne & 107.22 & 107.21 & 109.39 & 105.52 & 107.53 & 120 \\
\hline Schaffhouse & 102.29 & 102.93 & 95.53 & 111.06 & 102.14 & 106 \\
\hline Appenzell Rh.-Ext. & 80.79 & 95.45 & 83.43 & 82.25 & 84.81 & 59 \\
\hline Appenzell Rh.-Int. & 83.36 & 105.49 & 82.49 & 71.39 & 85.13 & 60 \\
\hline Saint-Gall & 86.48 & 101.13 & 91.74 & 98.58 & 93.41 & 82 \\
\hline Grisons & 87.12 & 100.89 & 101.52 & 70 & 90.77 & 75 \\
\hline Argovie & 98.8 & 105.99 & 90.33 & 110.46 & 100.03 & 100 \\
\hline Soleure & 91.51 & 102.51 & 88.46 & 103.52 & 95.2 & 87 \\
\hline Glaris & 113.65 & 90.98 & 80.86 & 77.3 & 92.01 & 78 \\
\hline Vaud & 98.77 & 87.8 & 98.47 & 106.17 & 97.96 & 95 \\
\hline Valais & 74.23 & 71.99 & 70 & 81.19 & 73.9 & 30 \\
\hline Neuchâtel & 87.53 & 76.48 & 84.35 & 88.65 & 84.59 & 58 \\
\hline Geneva & 112.65 & 85.49 & 126.35 & 111.1 & 111.02 & 130 \\
\hline Jura & 70 & 73.41 & 72.27 & 84.98 & 74.36 & 31 \\
\hline Switzerland & 100 & 100 & 100 & 100 & 100 & 100 \\
\hline Max/min ratio & 1.11 & 1.61 & 1.75 & 1.41 & 1.63 & 5.06 \\
\hline
\end{tabular}

Sources: Finances publiques en Suisse 2001, A.F.F., Berne: 76; Ordonnance du 17 novembre 1999 fixant la capacité financière des cantons pour les années 2000 et 2001, RS 613.11 
Table 3: Growth of the public sector 1970-2001, in millions SFr.

\begin{tabular}{|c|c|c|c|c|c|c|c|c|c|c|c|c|c|c|c|}
\hline & \multicolumn{2}{|c|}{1970} & \multicolumn{3}{|c|}{1980} & \multicolumn{3}{|c|}{1990} & \multicolumn{4}{|c|}{2000} & \multicolumn{3}{|c|}{2001} \\
\hline & $\begin{array}{c}\text { Million } \\
\text { SFr }\end{array}$ & $\begin{array}{c}\text { Share in } \\
\%\end{array}$ & $\begin{array}{c}\text { Million } \\
\text { SFr }\end{array}$ & $\begin{array}{c}\text { Share in } \\
\%\end{array}$ & $\begin{array}{c}\text { Growth } \\
\text { rate } \\
1970- \\
80 \\
\end{array}$ & $\begin{array}{c}\text { Million } \\
\text { SFr }\end{array}$ & $\begin{array}{c}\text { Share in } \\
\%\end{array}$ & \begin{tabular}{|c|} 
Growth \\
rate \\
$1980-$ \\
90 \\
\end{tabular} & $\begin{array}{c}\text { Million } \\
\text { SFr }\end{array}$ & $\begin{array}{c}\text { Share in } \\
\%\end{array}$ & \begin{tabular}{|c|} 
Growth \\
rate \\
$1990-$ \\
2000 \\
\end{tabular} & $\begin{array}{c}\text { Growth } \\
\text { rate } \\
1970- \\
2000 \\
\end{array}$ & $\begin{array}{c}\text { Million } \\
\text { SFr }\end{array}$ & $\begin{array}{c}\text { Share in } \\
\%\end{array}$ & \begin{tabular}{|c|} 
Growth \\
rate \\
$1990-$ \\
2001 \\
\end{tabular} \\
\hline 1 & 2 & 3 & 4 & 5 & 6 & 7 & 8 & 9 & 10 & 11 & 12 & 13 & 14 & 15 & 16 \\
\hline Confederation & 7,834 & 32.36 & 17,532 & 31.34 & 1.24 & 31,616 & 30.70 & 0.80 & 48,208 & 32.36 & 0.52 & 5.15 & 51,136 & 32.62 & 0.62 \\
\hline Cantons & 9,533 & 39.38 & 21,926 & 39.20 & 1.30 & 41,116 & 39.93 & 0.88 & 60,151 & 40.38 & 0.46 & 5.31 & 63,935 & 40.78 & 0.55 \\
\hline Communes & 6,840 & 28.26 & 16,476 & 29.46 & 1.41 & 30,245 & 29.37 & 0.84 & 40,599 & 27.26 & 0.34 & 4.94 & 41,709 & 26.60 & 0.38 \\
\hline Total $^{*}$ & 24,207 & 100.00 & 55,934 & 100.00 & 1.31 & 102,977 & 100.00 & 0.84 & 148,958 & 100.00 & 0.45 & 5.15 & 156,780 & 100.00 & 0.52 \\
\hline $\begin{array}{l}\text { Total without } \\
\text { double } \\
\text { accounting }\end{array}$ & 20,285 & & 47,240 & & & 86,614 & & & 123,612 & & & & & & \\
\hline GDP & 90,558 & & 180,305 & & & 327,584 & & & 415,529 & & & & 422,485 & & \\
\hline$\%$ GDP & 22.4 & & 26.2 & & & 26.4 & & & 29.7 & & & & 31.3 & & \\
\hline
\end{tabular}

Source: "Finances publiques en Suisse 2001", A.F.F., Berne, 2003: 2-3. *Data not consolidated; without social security expenditures

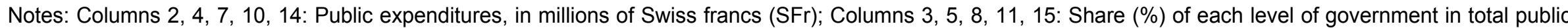

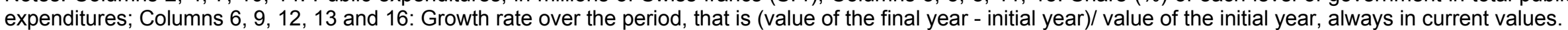


Table 4: Public expenditures, 2001

\begin{tabular}{|c|c|c|c|c|c|c|c|}
\hline \multirow[b]{2}{*}{ Expenditure function } & \multicolumn{4}{|c|}{ Public expenditures in $1000 \mathrm{SFr}$} & \multicolumn{3}{|c|}{$\begin{array}{c}\text { Expenditure shares between gov. } \\
\text { tiers (\%) }\end{array}$} \\
\hline & Confederation & Cantons & communes & total & Confederation & Cantons & communes \\
\hline 1 & 2 & 3 & 4 & 5 & 6 & 7 & 8 \\
\hline Administration & $1,912,934$ & $3,440,765$ & $3,691,204$ & $9,044,903$ & 21.15 & 38.04 & 40.81 \\
\hline Public order & 632,111 & $5,009,173$ & $1,897,310$ & $7,538,594$ & 8.38 & 66.45 & 25.17 \\
\hline police & 167,482 & $2,331,340$ & 780,679 & $3,279,501$ & 5.11 & 71.09 & 23.80 \\
\hline justice & 95,699 & $1,053,602$ & 41,655 & $1,190,956$ & 8.04 & 88.47 & 3.50 \\
\hline fire defense & 0 & 64,935 & 495,728 & 560,663 & 0.00 & 11.58 & 88.42 \\
\hline other & 368,930 & $1,559,296$ & 579,248 & $2,507,474$ & 14.71 & 62.19 & 23.10 \\
\hline National defense & $4,956,846$ & 257,882 & 238,619 & $5,453,347$ & 90.90 & 4.73 & 4.38 \\
\hline army & $4,870,197$ & 167,401 & 56,868 & $5,094,466$ & 95.60 & 3.29 & 1.12 \\
\hline civil defense & 86,649 & 90,481 & 181,751 & 358,881 & 24.14 & 25.21 & 50.64 \\
\hline Foreign Affairs & $2,691,469$ & 0 & 0 & $2,691,469$ & 100.00 & 0.00 & 0.00 \\
\hline Education & $3,650,226$ & $15,598,801$ & $9,662,846$ & $28,911,873$ & 12.63 & 53.95 & 33.42 \\
\hline kindergarten & 0 & 386,690 & 650,676 & $1,037,366$ & 0.00 & 37.28 & 62.72 \\
\hline public schools & 15,951 & $5,708,130$ & $7,579,345$ & $13,303,426$ & 0.12 & 42.91 & 56.97 \\
\hline special schools & 0 & 610,695 & 597,957 & $1,208,652$ & 0.00 & 50.53 & 49.47 \\
\hline $\begin{array}{l}\text { professional } \\
\text { teaching centers }\end{array}$ & 455,434 & $2,787,634$ & 664,699 & $3,907,767$ & 11.65 & 71.34 & 17.01 \\
\hline colleges & 11,932 & $1,900,809$ & 88,286 & $2,001,027$ & 0.60 & 94.99 & 4.41 \\
\hline $\begin{array}{l}\text {. higher technical } \\
\text { schools }\end{array}$ & 18,973 & 229,176 & 3,899 & 252,048 & 7.53 & 90.93 & 1.55 \\
\hline $\begin{array}{l}\text {. universities, } \\
\text { research }\end{array}$ & $2,392,798$ & $3,624,024$ & 19,473 & $6,036,295$ & 39.64 & 60.04 & 0.32 \\
\hline . others & 755,138 & 351,643 & 58,511 & $1,165,292$ & 64.80 & 30.18 & 5.02 \\
\hline $\begin{array}{l}\text { Culture, leisure and } \\
\text { sports }\end{array}$ & 780,352 & $1,297,457$ & $2,205,995$ & $4,283,804$ & 18.22 & 30.29 & 51.50 \\
\hline . culture & 472,976 & 654,559 & 838,387 & $1,965,922$ & 24.06 & 33.30 & 42.65 \\
\hline . sports & 136,261 & 130,967 & 761,753 & $1,028,981$ & 13.24 & 12.73 & 74.03 \\
\hline . others & 171,115 & 511,931 & 605,855 & $1,288,901$ & 13.28 & 39.72 & 47.01 \\
\hline Health & 227,653 & $11,025,989$ & $7,741,352$ & $18,994,994$ & 1.20 & 58.05 & 40.75 \\
\hline hospitals & 9,299 & $8,436,604$ & \begin{tabular}{|l|}
$5,629,002$ \\
\end{tabular} & $14,074,905$ & 0.07 & 59.94 & 39.99 \\
\hline . others & 218,354 & $2,589,385$ & $2,112,350$ & $4,920,089$ & 4.44 & 52.63 & 42.93 \\
\hline $\begin{array}{l}\text { Social Affairs, } \\
\text { solidarity }\end{array}$ & $12,529,165$ & $11,315,825$ & $5,885,297$ & $29,730,287$ & 42.14 & 38.06 & 19.80 \\
\hline old-age pensions & $4,833,915$ & $1,121,513$ & 210,351 & $6,165,779$ & 78.40 & 18.19 & 3.41 \\
\hline . invalidity insurance & $3,575,494$ & $1,181,558$ & 172,751 & $4,929,803$ & 72.53 & 23.97 & 3.50 \\
\hline health insurance & $1,918,374$ & $3,032,617$ & 428,620 & $5,379,611$ & 35.66 & 56.37 & 7.97 \\
\hline $\begin{array}{l}\text {. other social } \\
\text { insurances }\end{array}$ & 931,752 & $2,190,717$ & 886,585 & $4,009,054$ & 23.24 & 54.64 & 22.11 \\
\hline social housing & 242,076 & 179,860 & 48,097 & 470,033 & 51.50 & 38.27 & 10.23 \\
\hline $\begin{array}{l}\text { homes for old age } \\
\text { pensioners }\end{array}$ & 0 & 37,581 & 927,007 & 964,588 & 0.00 & 3.90 & 96.10 \\
\hline individual social aid & $1,027,554$ & $2,685,624$ & $2,596,472$ & $6,309,650$ & 16.29 & 42.56 & 41.15 \\
\hline . others & 0 & 886,355 & 615,414 & $1,501,769$ & 0.00 & 59.02 & 40.98 \\
\hline $\begin{array}{l}\text { Transportation and } \\
\text { roads }\end{array}$ & $8,680,481$ & $6,045,738$ & $3,018,192$ & $17,744,411$ & 48.92 & 34.07 & 17.01 \\
\hline roads & $2,897,050$ & $4,714,058$ & $2,432,815$ & $10,043,923$ & 28.84 & 46.93 & 24.22 \\
\hline railways & $3,324,923$ & 0 & 0 & $3,324,923$ & 100.00 & 0.00 & 0.00 \\
\hline $\begin{array}{l}\text { regional public } \\
\text { transportation }\end{array}$ & 913,251 & $1,267,366$ & 564,353 & $2,744,970$ & 33.27 & 46.17 & 20.56 \\
\hline others & $1,545,257$ & 64,314 & 21,024 & $1,630,595$ & 94.77 & 3.94 & 1.29 \\
\hline Environment & 812,866 & $1,527,093$ & $3,603,008$ & $5,942,967$ & 13.68 & 25.70 & 60.63 \\
\hline water & 0 & 42,023 & 279,982 & 322,005 & 0.00 & 13.05 & 86.95 \\
\hline
\end{tabular}


69

\begin{tabular}{|c|c|c|c|c|c|c|c|}
\hline $\begin{array}{l}\text { sewage and water } \\
\text { purification }\end{array}$ & 176,202 & 511,970 & $1,547,783$ & $2,235,955$ & 7.88 & 22.90 & 69.22 \\
\hline $\begin{array}{l}\text { garbage collection } \\
\text { and disposal }\end{array}$ & 45,996 & 172,941 & 913,095 & $1,132,032$ & 4.06 & 15.28 & 80.66 \\
\hline $\begin{array}{l}\text {. land planning, } \\
\text { zoning }\end{array}$ & 370,842 & 549,542 & 513,173 & $1,433,557$ & 25.87 & 38.33 & 35.80 \\
\hline others & 219,826 & 250,617 & 348,975 & 819,418 & 26.83 & 30.58 & 42.59 \\
\hline Economy & $4,787,923$ & $4,490,744$ & 820,160 & $10,098,827$ & 47.41 & 44.47 & 8.12 \\
\hline agriculture & $3,962,176$ & $2,930,530$ & 98,725 & $6,991,431$ & 56.67 & 41.92 & 1.41 \\
\hline forestry & 255,657 & 494,608 & 353,756 & $1,104,021$ & 23.16 & 44.80 & 32.04 \\
\hline others & 570,090 & $1,065,606$ & 367,679 & $2,003,375$ & 28.46 & 53.19 & 18.35 \\
\hline Finance & $9,474,461$ & $3,925,436$ & $2,945,026$ & $16,344,923$ & 57.97 & 24.02 & 18.02 \\
\hline . equalization & 0 & 747,715 & 467,916 & $1,215,631$ & 0.00 & 61.51 & 38.49 \\
\hline revenue-sharing & $5,881,071$ & 593,661 & 0 & $6,474,732$ & 90.83 & 9.17 & 0.00 \\
\hline $\begin{array}{l}\text { public debt interest } \\
\text { and management }\end{array}$ & $3,593,390$ & $2,433,204$ & $2,446,964$ & $8,473,558$ & 42.41 & 28.72 & 28.88 \\
\hline others & 0 & 150,856 & 30,146 & 181,002 & 0.00 & 83.34 & 16.66 \\
\hline Total & $51,136,487$ & $63,934,903$ & $41,709,009$ & $156,780,399$ & 32.62 & 40.78 & 26.60 \\
\hline
\end{tabular}


Table 5: Public revenues, 2001

\begin{tabular}{|c|c|c|c|c|c|c|c|}
\hline \multirow[b]{2}{*}{ Revenue category } & \multicolumn{4}{|c|}{ Public revenues in $1000 \mathrm{SFr}$} & \multicolumn{3}{|c|}{$\begin{array}{c}\text { Revenue shares between gov. } \\
\text { tiers (\%) }\end{array}$} \\
\hline & Confederation & Cantons & communes & Total & Confederation & Cantons & communes \\
\hline 1 & 2 & 3 & 4 & 5 & 6 & 7 & 8 \\
\hline Taxes on income and wealth & $16,568,376$ & $28,050,092$ & $22,421,923$ & $67,040,391$ & 24.71 & 41.84 & 33.45 \\
\hline Income of individuals & $6,350,624$ & $18,070,485$ & $15,721,070$ & $40,142,179$ & 15.82 & 45.02 & 39.16 \\
\hline Wealth of individuals & 0 & $2,392,268$ & $2,163,122$ & $4,555,390$ & 0.00 & 52.52 & 47.48 \\
\hline Corporate profits & $5,868,701$ & $4,406,141$ & $2,613,779$ & $12,888,621$ & 45.53 & 34.19 & 20.28 \\
\hline Corporate capital & 0 & 776,160 & 574,854 & $1,351,014$ & 0.00 & 57.45 & 42.55 \\
\hline Immovable property & 0 & 167,707 & 549,395 & 717,102 & 0.00 & 23.39 & 76.61 \\
\hline Capital gains & 0 & 500,938 & 426,368 & 927,306 & 0.00 & 54.02 & 45.98 \\
\hline Inheritance and gifts & 0 & $1,053,223$ & 101,997 & $1,155,220$ & 0.00 & 91.17 & 8.83 \\
\hline $\begin{array}{l}\text { Transfer of immovable } \\
\text { property }\end{array}$ & 0 & 683,170 & 271,338 & 954,508 & 0.00 & 71.57 & 28.43 \\
\hline Withholding tax & 895,846 & 0 & 0 & 895,846 & 100.00 & 0.00 & 0.00 \\
\hline Stamp tax & $3,453,205$ & 0 & 0 & $3,453,205$ & 100.00 & 0.00 & 0.00 \\
\hline $\begin{array}{l}\text { Consumption or expenditure } \\
\text { taxes }\end{array}$ & $26,304,820$ & $1,784,528$ & 58,482 & $28,147,830$ & 93.45 & 6.34 & 0.21 \\
\hline Turnover & $17,033,104$ & 0 & 0 & $17,033,104$ & 100.00 & 0.00 & 0.00 \\
\hline Tobacco & $1,809,465$ & 0 & 0 & $1,809,465$ & 100.00 & 0.00 & 0.00 \\
\hline Customs and imports duties & $1,059,228$ & 0 & 0 & $1,059,228$ & 100.00 & 0.00 & 0.00 \\
\hline Motor fuel and petrol & $4,894,548$ & 0 & 0 & $4,894,548$ & 100.00 & 0.00 & 0.00 \\
\hline Motorways voucher & 977,872 & 0 & 0 & 977,872 & 100.00 & 0.00 & 0.00 \\
\hline Motor vehicles & 0 & $1,725,224$ & 0 & $1,725,224$ & 0.00 & 100.00 & 0.00 \\
\hline Entertainments & 0 & 14,433 & 25,339 & 39,772 & 0.00 & 36.29 & 63.71 \\
\hline Dogs & 0 & 9,210 & 21,089 & 30,299 & 0.00 & 30.40 & 69.60 \\
\hline Others & 530,603 & 35,661 & 12,054 & 578,318 & 91.75 & 6.17 & 2.08 \\
\hline Fiscal monopolies, licenses & 536,835 & 723,251 & 135,900 & $1,395,986$ & 38.46 & 51.81 & 9.74 \\
\hline $\begin{array}{l}\text { Revenues from public } \\
\text { property }\end{array}$ & $1,801,548$ & $3,035,635$ & $2,789,413$ & $7,626,596$ & 23.62 & 39.80 & 36.57 \\
\hline Interests, dividends & 685,790 & 874,544 & 613,324 & $2,173,658$ & 31.55 & 40.23 & 28.22 \\
\hline Rents & 42,140 & 406,625 & $1,355,983$ & $1,804,748$ & 2.33 & 22.53 & 75.13 \\
\hline Others & $1,073,618$ & $1,754,466$ & 820,106 & $3,648,190$ & 29.43 & 48.09 & 22.48 \\
\hline Revenue-sharing & 5,879 & $4,525,617$ & $1,335,500$ & $5,866,996$ & 0.10 & 77.14 & 22.76 \\
\hline Federal Direct Tax & 0 & $3,681,560$ & ** - & $3,681,560$ & 0.00 & 100.00 & 0.00 \\
\hline Withholding tax & 0 & 85,350 & - & 85,350 & 0.00 & 100.00 & 0.00 \\
\hline Military tax & 0 & 34,179 & - & 34,179 & 0.00 & 100.00 & 0.00 \\
\hline Others & 5,879 & 724,528 & & 730,407 & 0.80 & 99.20 & 0.00 \\
\hline Grants-in-aid & 10,483 & $15,987,794$ & $6,150,565$ & $22,148,842$ & 0.05 & 72.18 & 27.77 \\
\hline Federal grants-in-aid & 0 & $10,904,885$ & 14,097 & $10,918,982$ & 0.00 & 99.87 & 0.13 \\
\hline Cantonal & 10,483 & *838'834 & $5,644,758$ & $5,655,241$ & 0.19 & 0.00 & 99.81 \\
\hline Communal & 0 & $4,340,837$ & *1'727'259 & $4,340,837$ & 0.00 & 100.00 & 0.00 \\
\hline Others & 0 & 742,072 & 491,710 & $1,233,782$ & 0.00 & 60.15 & 39.85 \\
\hline Indemnities and sales & $1,525,472$ & $9,222,386$ & $11,466,140$ & $22,213,998$ & 6.87 & 41.52 & 51.62 \\
\hline Administrative fees & 294,743 & $1,424,490$ & 404,656 & $2,123,889$ & 13.88 & 67.07 & 19.05 \\
\hline $\begin{array}{l}\text { Sales of products and } \\
\text { services }\end{array}$ & 420,667 & $5,117,834$ & $7,709,333$ & $13,247,834$ & 3.18 & 38.63 & 58.19 \\
\hline Sales of property & 65,285 & 31,741 & 79,957 & 176,983 & 36.89 & 17.93 & 45.18 \\
\hline Others & 744,777 & $2,648,321$ & $3,272,194$ & $6,665,292$ & 11.17 & 39.73 & 49.09 \\
\hline Reimbursements & $2,682,798$ & $1,861,494$ & 99,058 & $4,643,350$ & 57.78 & 40.09 & 2.13 \\
\hline Total & $49,436,211$ & $65,190,797$ & $44,456,981$ & $159,083,989$ & 31.08 & 40.98 & 27.95 \\
\hline
\end{tabular}

Source: "Finances publiques en Suisse 2001", A.F.F., Berne, 2003: 24, 28-29, 46, 80, 145, 147, 149. * consolidated data; this figure is not included in the total; ${ }^{* *}$ subtotals are not given. 
Table 6: Revenue structure of government tiers, 2001

\begin{tabular}{|l|l|l|l|l|l|l|l|}
\hline & \multicolumn{2}{|c|}{ Confederation } & \multicolumn{2}{c|}{ Cantons } & \multicolumn{2}{c|}{ communes } & average \\
\hline \multicolumn{1}{|c|}{1} & $1000 \mathrm{SFr}$ & $\%$ & $1000 \mathrm{SFr}$. & $\%$ & $1000 \mathrm{SFr}$. & $\%$ & $\%$ \\
\hline Taxes on income and wealth & \multicolumn{1}{|c|}{2} & 3 & 4 & 5 & 6 & 7 & 8 \\
\hline Consumption or expenditure taxes & $26,304,376$ & 33.5 & $28,050,092$ & 43.0 & $22,421,923$ & 50.4 & 42.1 \\
\hline Fiscal monopolies, licenses & 536,835 & 1.1 & 723,251 & 1.1 & 135,900 & 0.3 & 0.9 \\
\hline Revenues from public property & $1,801,548$ & 3.6 & $3,035,635$ & 4.7 & $2,789,413$ & 6.3 & 4.8 \\
\hline Revenue-sharing & 5,879 & 0.0 & $4,525,617$ & 6.9 & $1,335,500$ & 3.0 & 3.7 \\
\hline Grants-in-aid & 10,483 & 0.0 & $15,987,794$ & 24.5 & $6,150,565$ & 13.8 & 13.9 \\
\hline Federal grants-in-aid & 0 & & $10,904,885$ & 16.7 & 14,097 & & \\
\hline Cantonal & 10,483 & & $838,834^{\star}$ & & $5,644,758$ & 12.7 & \\
\hline Communal & 0 & & $4,340,837$ & 6.7 & $\star 1 ' 727 ' 259$ & & \\
\hline Fees, user charges and sales & $1,525,472$ & 3.1 & $9,222,386$ & 14.1 & $11,466,140$ & 25.8 & 14.0 \\
\hline Reimbursements & $2,682,798$ & 5.4 & $1,861,494$ & 2.9 & 99,058 & 0.2 & 2.9 \\
\hline Total & $\mathbf{4 9 , 4 3 6 , 2 1 1}$ & $\mathbf{1 0 0 . 0}$ & $\mathbf{6 5 , 1 9 0 , 7 9 7}$ & $\mathbf{1 0 0 . 0}$ & $\mathbf{4 4 , 4 5 6 , 9 8 1}$ & $\mathbf{1 0 0 . 0}$ & $\mathbf{1 0 0 . 0}$ \\
\hline
\end{tabular}

Source: authors' calculation based on Table 5.

${ }^{*}$ Consolidated data; this figure is not included in the total. 
Table 7: Financial dependence of the cantons, 2001

\begin{tabular}{|c|c|c|c|c|c|c|c|}
\hline \multirow[b]{2}{*}{ Canton } & \multirow{2}{*}{$\begin{array}{c}\text { Federal } \\
\text { Grants-in- } \\
\text { Aid } \\
\text { (1000 SFr) }\end{array}$} & \multirow[b]{2}{*}{$\begin{array}{l}\text { Revenue } \\
\text { Sharing } \\
\text { (1000 SFr) }\end{array}$} & \multirow[b]{2}{*}{$\begin{array}{l}\text { Total Fiscal } \\
\text { Resources } \\
\text { (1000 SFr) }\end{array}$} & \multicolumn{3}{|c|}{\begin{tabular}{|c} 
Financial dependence in \\
$\%$
\end{tabular}} & \multirow[b]{2}{*}{$\begin{array}{c}\text { NIC/capita } \\
\text { (SFr) }\end{array}$} \\
\hline & & & & \begin{tabular}{|c|} 
Federal \\
Grants- \\
in-Aid \\
\end{tabular} & $\begin{array}{c}\text { Revenue } \\
\text { Sharing }\end{array}$ & Total & \\
\hline 1 & 2 & 3 & 4 & $5=2 / 4$ & $6=3 / 4$ & $\begin{array}{c}7= \\
(2+3) / 4\end{array}$ & $10, \frac{1}{4}$ \\
\hline Zoug & 78,538 & 147,848 & 848,188 & 9.3 & 17.4 & 26.7 & 71,733 \\
\hline Basle-Town & 254,730 & 121,859 & $4,010,686$ & 6.4 & 3.0 & 9.4 & 63,002 \\
\hline Zurich & $1,322,780$ & 628,949 & $10,557,020$ & 12.5 & 6.0 & 18.5 & 58,540 \\
\hline Nidwald & 91,492 & 21,099 & 314,822 & 29.1 & 6.7 & 35.8 & 53,189 \\
\hline Basle-Land & 224,071 & 78,484 & $2,209,127$ & 10.1 & 3.6 & 13.7 & 51,853 \\
\hline Geneva & 373,434 & 275,240 & $6,611,547$ & 5.6 & 4.2 & 9.8 & 49,969 \\
\hline Schaffhouse & 59,954 & 38,510 & 561,180 & 10.7 & 6.9 & 17.5 & 49,322 \\
\hline Argovie & 464,626 & 241,877 & $3,516,202$ & 13.2 & 6.9 & 20.1 & 48,808 \\
\hline Schwyz & 155,599 & 106,922 & 756,413 & 20.6 & 14.1 & 34.7 & 47,862 \\
\hline Vaud & 922,361 & 296,596 & $6,169,875$ & 14.9 & 4.8 & 19.8 & 47,748 \\
\hline Glaris & 52,319 & 25,964 & 328,772 & 15.9 & 7.9 & 23.8 & 47,249 \\
\hline Uri & 212,756 & 19,846 & 454,333 & 46.8 & 4.4 & 51.2 & 42,966 \\
\hline Appenzell Rh.-Ext. & 74,419 & 35,329 & 369,984 & 20.1 & 9.5 & 29.7 & 42,934 \\
\hline Soleure & 267,510 & 97,591 & $1,538,637$ & 17.4 & 6.3 & 23.7 & 42,927 \\
\hline Saint-Gall & 616,237 & 189,385 & $3,465,658$ & 17.8 & 5.5 & 23.2 & 42,926 \\
\hline Thurgovie & 201,758 & 102,576 & $1,468,142$ & 13.7 & 7.0 & 20.7 & 42,357 \\
\hline Grisons & 682,921 & 105,933 & $1,803,620$ & 37.9 & 5.9 & 43.7 & 41,339 \\
\hline Lucerne & 541,802 & 172,005 & $2,692,765$ & 20.1 & 6.4 & 26.5 & 41,136 \\
\hline Berne & $1,668,485$ & 511,452 & $7,698,561$ & 21.7 & 6.6 & 28.3 & 40,697 \\
\hline Neuchâtel & 436,212 & 128,961 & $1,577,809$ & 27.6 & 8.2 & 35.8 & 39,858 \\
\hline Fribourg & 557,440 & 165,044 & $2,101,742$ & 26.5 & 7.9 & 34.4 & 37,748 \\
\hline Tessin & 425,219 & 203,093 & $2,604,943$ & 16.3 & 7.8 & 24.1 & 36,665 \\
\hline Obwald & 112,975 & 26,271 & 278,191 & 40.6 & 9.4 & 50.1 & 35,427 \\
\hline Valais & 766,589 & 246,669 & $2,400,310$ & 31.9 & 10.3 & 42.2 & 35,309 \\
\hline Jura & 309,965 & 57,622 & 742,905 & 41.7 & 7.8 & 49.5 & 33,616 \\
\hline Appenzell Rh.-Int. & 30,693 & 12,577 & 109,365 & 28.1 & 11.5 & 39.6 & 32,940 \\
\hline Switzerland & 885 & $4,057,702$ & $65,190,797$ & 16.7 & 6.2 & 23.0 & 46,970 \\
\hline
\end{tabular}

Source: Finances publiques en Suisse 2001, A.F.F., Berne. Columns 2 and 3: page 73; column 4: page 67 (= Table 1 col. 10); column 8: see Table 1. 
Table 8: Indices of tax burden in the cantons and communes, 2001 (in points)

\begin{tabular}{|c|c|c|c|c|c|c|}
\hline \multirow[b]{2}{*}{ Cantons } & \multicolumn{2}{|c|}{ Individual } & \multicolumn{2}{|c|}{ Legal Entities } & \multirow{2}{*}{$\begin{array}{c}\text { Motor } \\
\text { Vehicle }\end{array}$} & \multirow{2}{*}{$\begin{array}{l}\text { Global } \\
\text { Index }\end{array}$} \\
\hline & Income & Wealth & Profit & Capital & & \\
\hline 1 & 2 & 3 & 4 & 5 & 6 & 7 \\
\hline Zurich & 86.3 & 56.2 & 106.5 & 100.5 & 96.4 & 87 \\
\hline Berne & 115.9 & 113.6 & 101.2 & 68.4 & 137.8 & 115 \\
\hline Lucerne & 124.8 & 112.3 & 93.4 & 118.7 & 96.3 & 121 \\
\hline Uri & 118.9 & 84.1 & 111.2 & 121.4 & 80.6 & 114 \\
\hline Schwyz & 67.4 & 48.6 & 54.2 & 52 & 96.1 & 65 \\
\hline Obwald & 127.8 & 108.5 & 100.4 & 91.3 & 89.8 & 123 \\
\hline Nidwald & 79.6 & 40.2 & 76.1 & 50 & 81.6 & 75 \\
\hline Glaris & 110.4 & 72.5 & 106 & 105.9 & 103.2 & 106 \\
\hline Zoug & 49.5 & 50 & 58 & 22.7 & 82.8 & 51 \\
\hline Fribourg & 126.6 & 167.1 & 105.5 & 103.4 & 108 & 127 \\
\hline Soleure & 115.1 & 94.1 & 102.7 & 124.8 & 88.4 & 112 \\
\hline Bâle-Ville & 117.4 & 132.7 & 107.8 & 148.4 & 107.7 & 119 \\
\hline Bâle-Campagne & 88.7 & 97.4 & 105.7 & 213.2 & 110.8 & 94 \\
\hline Schaffhouse & 116.2 & 96.4 & 83.9 & 94.9 & 64.8 & 110 \\
\hline Appenzell Rh.-Ext. & 110.2 & 94.3 & 83.8 & 24.5 & 116.1 & 106 \\
\hline Appenzell Rh.-Int. & 90.9 & 67.6 & 73 & 22.8 & 97.1 & 85 \\
\hline Saint-Gall & 101.2 & 107.2 & 106.3 & 28.8 & 103.9 & 101 \\
\hline Grisons & 93.2 & 106.1 & 111.1 & 182.7 & 137 & 103 \\
\hline Argovie & 87.7 & 74 & 96.5 & 133.4 & 74.7 & 88 \\
\hline Thurgovie & 109 & 126.2 & 92.9 & 138 & 70.5 & 109 \\
\hline Tessin & 81.3 & 75.8 & 94.3 & 101.4 & 92.8 & 84 \\
\hline Vaud & 106.8 & 146.6 & 125.7 & 76.9 & 130.5 & 112 \\
\hline Valais & 109.7 & 299.4 & 97.1 & 135.6 & 53.6 & 121 \\
\hline Neuchâtel & 124 & 140.5 & 105.9 & 142 & 99.8 & 122 \\
\hline Geneva & 86 & 126.8 & 124.1 & 114.4 & 68.9 & 96 \\
\hline Jura & 132.4 & 172 & 100.3 & 134.4 & 125.5 & 132 \\
\hline Average & 100.0 & 100.0 & 100.0 & 100.0 & 100.0 & 100 \\
\hline Max/min ratio & 2.67 & 7.45 & 2.32 & 9.39 & 2.57 & 2.60 \\
\hline
\end{tabular}

Source: "Charge fiscale en Suisse 2001", A.F.F., Berne, 2002: 62, 76, 89. 
Table 9: Economic classification of public expenditures 2001

\begin{tabular}{|c|c|c|c|c|c|c|}
\hline \multirow{2}{*}{$\begin{array}{l}\text { Category of public } \\
\text { expenditure }\end{array}$} & \multicolumn{3}{|c|}{ in $1000 \mathrm{SFr}$} & \multicolumn{3}{|c|}{ in $\%$} \\
\hline & Confederation & Cantons & communes & Confederation & Cantons & communes \\
\hline 1 & 2 & 3 & 4 & 5 & 6 & 7 \\
\hline Current account & $19,938,391$ & $34,660,985$ & $27,317,580$ & 0.39 & 0.54 & 0.65 \\
\hline Personnel & $5,809,558$ & $23,414,798$ & $15,943,576$ & 0.11 & 0.37 & 0.38 \\
\hline Consumption & $4,851,329$ & $7,652,155$ & $8,906,188$ & 0.09 & 0.12 & 0.21 \\
\hline Interest & $3,396,433$ & $2,252,656$ & $1,999,901$ & 0.07 & 0.04 & 0.05 \\
\hline Revenue sharing & $5,881,071$ & $1,341,376$ & 467,915 & 0.12 & 0.02 & 0.01 \\
\hline Grants-in-aid & $23,091,206$ & $21,695,725$ & $9,147,587$ & 0.45 & 0.34 & 0.22 \\
\hline \multicolumn{7}{|l|}{ - public sector } \\
\hline Confederation & 0 & 8,738 & 0 & 0 & 0.00 & 0 \\
\hline . Cantons & $8,132,083$ & $836,139 *$ & $4,241,038$ & 0.16 & 0 & 0.10 \\
\hline communes & 0 & $4,893,492$ & $1,625,124^{*}$ & 0 & 0.08 & 0 \\
\hline - semi-public sector & $10,547,559$ & $4,090,905$ & 698,436 & 0.21 & 0.06 & 0.02 \\
\hline - foreign countries & $1,724,283$ & 0 & 0 & 0.03 & 0 & 0 \\
\hline - private sector & $2,687,281$ & $12,702,590$ & $4,208,113$ & 0.05 & 0.20 & 0.10 \\
\hline Capital account & $8,106,891$ & $7,578,191$ & $5,243,838$ & 0.16 & 0.12 & 0.13 \\
\hline Own investments & 892,930 & $5,167,961$ & $4,763,174$ & 0.02 & 0.08 & 0.11 \\
\hline Loans and contributions & $3,441,283$ & 317,650 & 109,794 & 0.07 & 0.00 & 0.00 \\
\hline Grants-in-aid & $3,772,678$ & $2,087,396$ & 363,177 & 0.07 & 0.03 & 0.01 \\
\hline \multicolumn{7}{|l|}{ - public sector } \\
\hline Confederation & 0 & 1,745 & 0 & 0 & 0.00 & 0 \\
\hline Cantons & $2,535,304$ & $2,695^{\star}$ & 99,799 & 0.05 & 0 & 0.00 \\
\hline communes & 0 & 751,266 & $102135^{\star}$ & 0 & 0.01 & 0 \\
\hline - semi-public sector & 914,037 & 416,451 & 112,259 & 0.02 & 0.01 & 0.003 \\
\hline - private sector & 323,337 & 917,934 & 151,119 & 0.01 & 0.01 & 0.004 \\
\hline Other & 0 & 5,184 & 7,693 & 0 & 0.0001 & 0.0002 \\
\hline Total & $51,136,488$ & $63,934,901$ & $41,709,005$ & 1.00 & 1.00 & 1.00 \\
\hline
\end{tabular}

Source: "Finances publiques en Suisse 2001", A.F.F., Berne, 2003: 22, 44, 78.

*consolidated data; this figure is not included in the total. 
Figure 1 Per capita cantonal income: growth rate 1980-2001 and disparities 2001

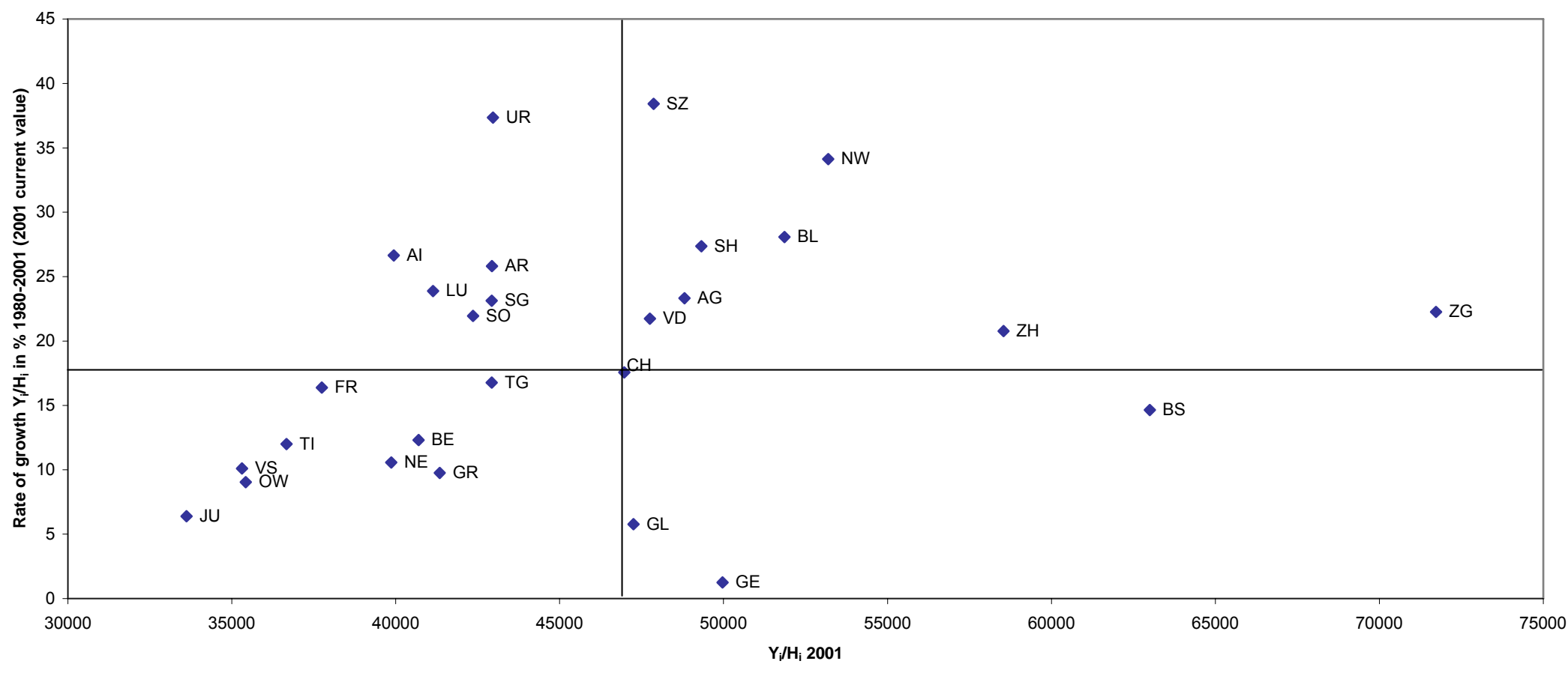

